\title{
Re-Interpretations of Gotlandic Picture Stones Based on the Reflectance Transformation Imaging Method (RTI): Some Examples
}

Sigmund Oehrl

Munich/Stockholm University

The picture stones ${ }^{\mathrm{I}}$ from the Isle of Gotland in the Baltic Sea are a unique source for the study of Germanic history of religion. These stone slabs, which have been inspired by late antique sepulchral monuments and iconography, ${ }^{2}$ were raised from the Migration Period until the end of the Viking Age. Even when most of the figures on the Gotland picture stones are still enigmatic, it is clearly proved that their iconography includes mythological and heroic motifs which in certain cases can reliably be interpreted against the background of Old Norse literature. The later picture stones, which offer an abundance of figurative depictions and narrative scenes, were dated by Sune Lindqvist, in his most relevant book Gotlands Bildsteine, published in I94I-1942, to the $8^{\text {th }}$ century (type C/D according to Lindqvist's classification). ${ }^{3}$ Recent research, however, has attested that monuments of that type were still being erected in the $9^{\text {th }}$ and ${ }_{1} 0^{\text {th }}$ centuries, ${ }^{4}$ the period of the earliest known scaldic and Eddic poetry. Thus, there is a chronological overlap of both sources, the written sources from Iceland and the iconographic sources from the Baltic isle of Gotland. As a result, it can, in favourable cases, be reasonable to connect these disparate traditions in order to interpret the carved pictures.

How to cite this book chapter:

Oehrl, S. 2019. Re-Interpretations of Gotlandic Picture Stones Based on the Reflectance Transformation Imaging Method (RTI): Some Examples. In: Wikström af Edholm, K., Jackson Rova, P., Nordberg, A., Sundqvist, O. \& Zachrisson, T. (eds.) Myth, Materiality, and Lived Religion: In Merovingian and Viking Scandinavia. Pp. I4I-189. Stockholm: Stockholm University Press. DOI: https://doi.org/Io.I6993/bay.g. License: CC-BY. 


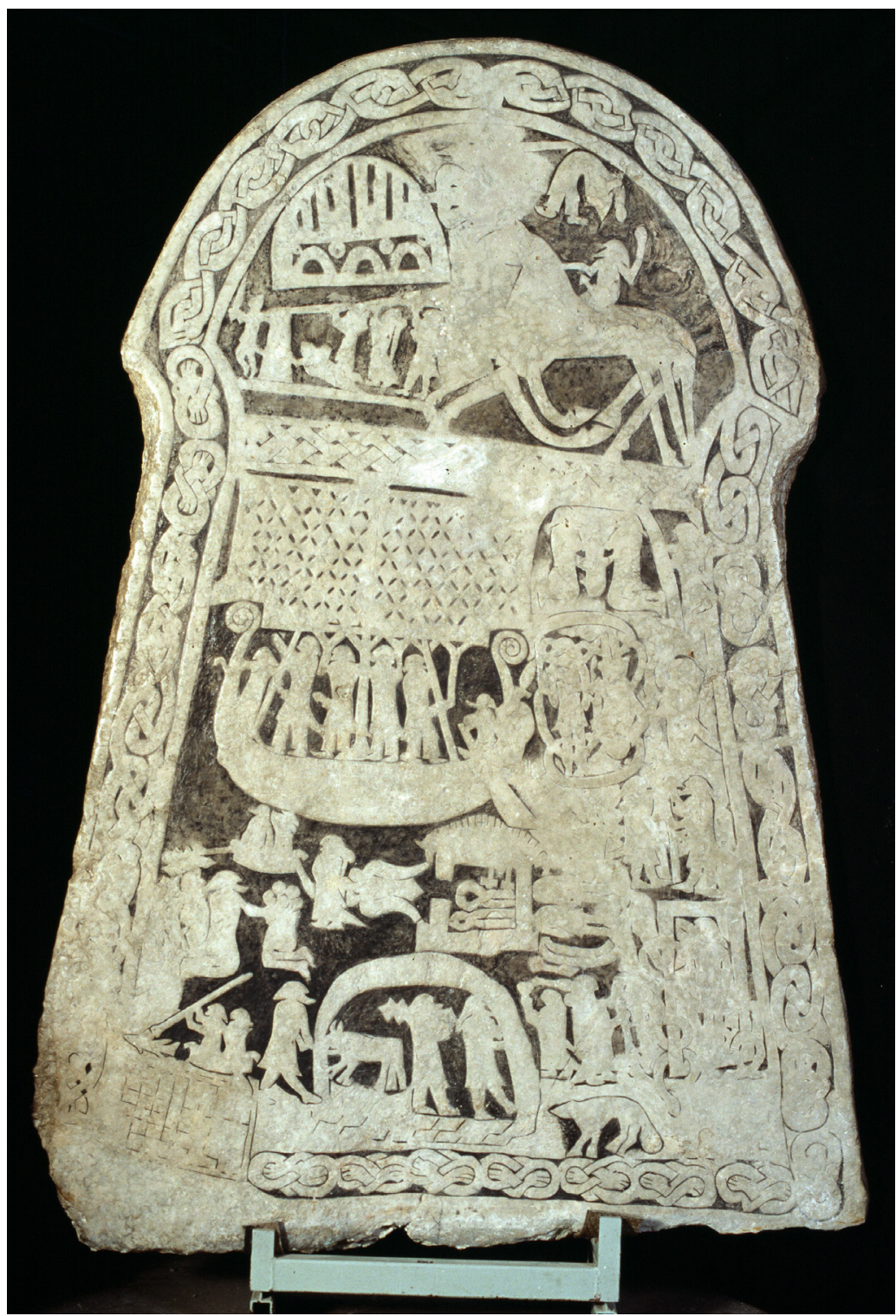

Figure 1. Ardre Church VIII (SHM). Photographer: Bengt A. Lundberg (SHM) 
The two prominent Viking picture stones (type D) Alskog Tjängvide $\mathrm{I}^{5}$ and Ardre Church VIII ${ }^{6}$ (Fig. I, on the top of the stone), for instance, bear the depiction of a horseman riding an eight-legged horse. Written sources from Iceland dating to the $\mathrm{I}_{3}{ }^{\text {th }}$ century talk about Óðinn's miraculous horse Sleipnir that was born with eight legs. ${ }^{7}$ Sleipnir is described as the best and the fastest of all horses. Its most special feature seems to be its ability to cross the border between the world of the living and the world of the dead. It is very likely that the horse on these picture stones represents Óðinn's horse Sleipnir, not less than three centuries before it was recorded literally. At least, the stone carvings document the same concept of a mythological, miraculously fast horse. On Ardre VIII can be seen a smithy, two beheaded men behind the building, a bird-like creature and a woman (Fig. I, in the lower part of the stone, beneath the ship). There is absolutely no doubt about the fact that this is a depiction of Wayland the Smith (Old Norse Volundr) and his cruel revenge, ${ }^{8}$ first recorded in the Eddic poem Volundarkviða, ${ }^{9}$ composed in Iceland in the $10^{\text {th }}$ century or even earlier. ${ }^{\text {I0 }}$ Examples like these clearly show that the picture stones from Gotland can bear mythological and heroic carvings and that using written sources in order to interpret them can be fruitful and reveals new information about the dating and distribution of certain narratives.

In addition, the iconography of these monuments can provide completely new insights into ancient Germanic and Viking religion, recording motifs that are not known from literally tradition. At this point I would like to present a hitherto unknown find from St. Valle in Rute Parish that I will publish and discuss in detail in my forthcoming book about Gotlandic picture stones. ${ }^{\text {II }}$

The fragment shows a man with horned headgear, hovering behind the stern of a ship, on the waves of the sea (Fig. 2), similar to the horned Eidolon figure who, on the Merovingian Period helmet plates (Fig. 3), assists the equestrian in throwing his spear, as a kind of divine helper in battle, a Germanic version of the numen victoriae. ${ }^{\mathrm{I} 2}$ In Old Norse literature there are no striking parallels to this depiction of a divine escort at sea. However, the motif on the Vendel plates can be connected to Old Norse written sources $^{\mathrm{I} 3}$ such as the skaldic poem Gráfeldardrápa written 


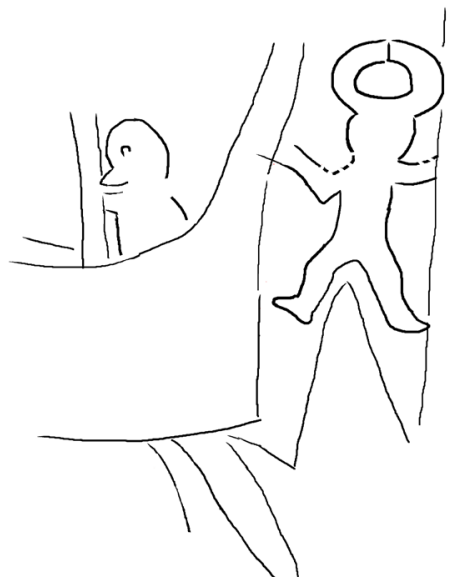

Figure 2. Unpublished fragment from Rute St. Valle (drawing S. Oehrl). Copyright: Sigmund Oehrl, License: CC-BY-NC-ND

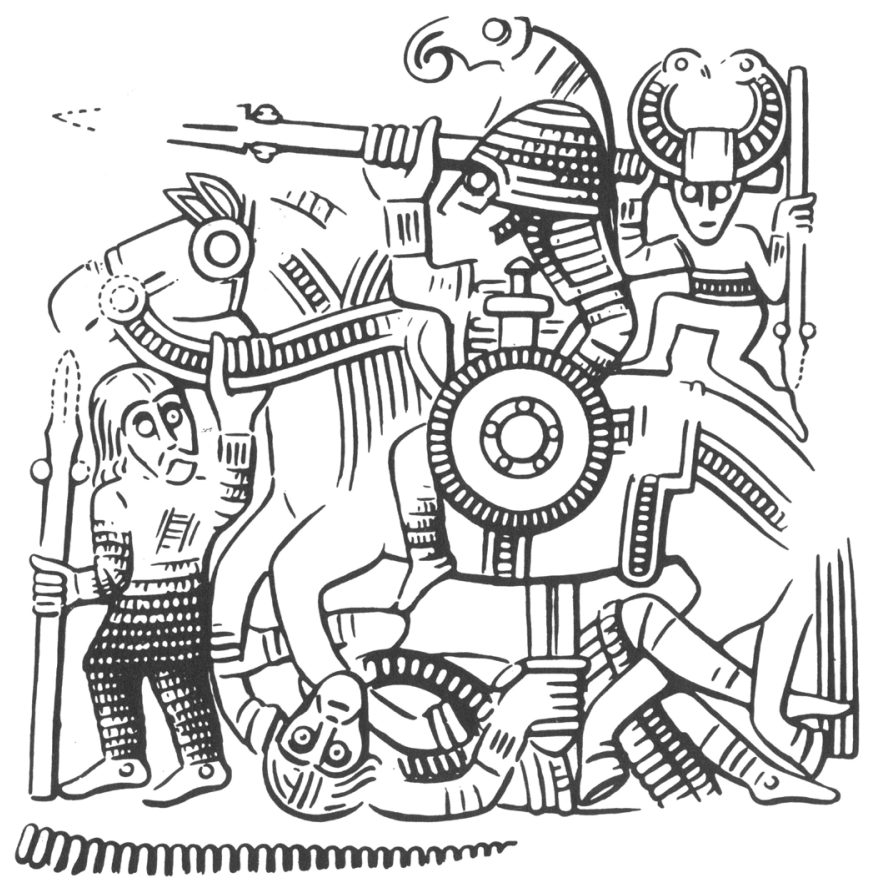

Figure 3. Helmet plate from Valsgärde 8 (drawing W. Lange, after Hauck I98I: fig. 26). 
by Glúmr Geirason (after $974 \mathrm{AD}$ ), telling that the gods guide or steer (stýra) the heroes on the battle field. In the Eddic poem Hloðskviða stanza 28 (probably $9^{\text {th }}$ century) the King of the Goths invokes Óðinn, god of war and father of the fallen, to steer his throwing spear (láti svá Óðinn flein fliúga).

As we have seen so far, the carved monuments from the isle of Gotland are an important and unique source for Germanic mythology and heroic legend. But there is a still unsolved problem that makes it almost impossible to make use of it entirely: The depictions on the picture stones are often quite hard to identify. The low reliefs are quite primitive and the carved lines are flat, almost invisible to the naked eye. In addition, they are often degraded by weathering or by footsteps. This was the main problem faced by Sune Lindqvist and his forerunners who prepared the edition of the Gotlandic monuments in I94I-I942 and it is still a major - but regrettably rarely noted - problem of recent picture stone research. ${ }^{14}$ Lindqvist darkened the location in order to use the light of an electric lamp which was placed in varying positions. In preparation for the photographs for his picture stone edition he then painted the grooves he regarded as having been carved by the artist's hand (Fig. 4-5).

As a result, these images of the stones, which still provide the main basis of research, reflect the individual view and estimation of one single person. Even though Lindqvist was a specialist and his work has unquestionably been of outstanding importance up to the present day, subsequent research realized that certain parts and details on the stones can be interpreted in several ways, while Lindqvist's illustrations represent only one possible perception (Fig. 6-7). ${ }^{15}$

There are different digital methods available today which can be applied in order to improve the picture stone documentation and to objectify our view of the depicted figures. That is what I try to do in my current research project, which will result in a monograph. One of these resources of digital archaeology is ${ }_{3}$ D-modelling. ${ }^{16}$ I myself use the photogrammetry method, which means creating ${ }_{3} \mathrm{D}$-models on the basis of photographs captured from different angles. The advantages of using ${ }_{3} \mathrm{D}$-models for iconography are numerous: the surface model can be rotated and 




Figure 4. Buttle Änge I, without paint. Photographer: Sune Lindqvist. Copyright: ATA, License: CC-BY-NC-ND. 


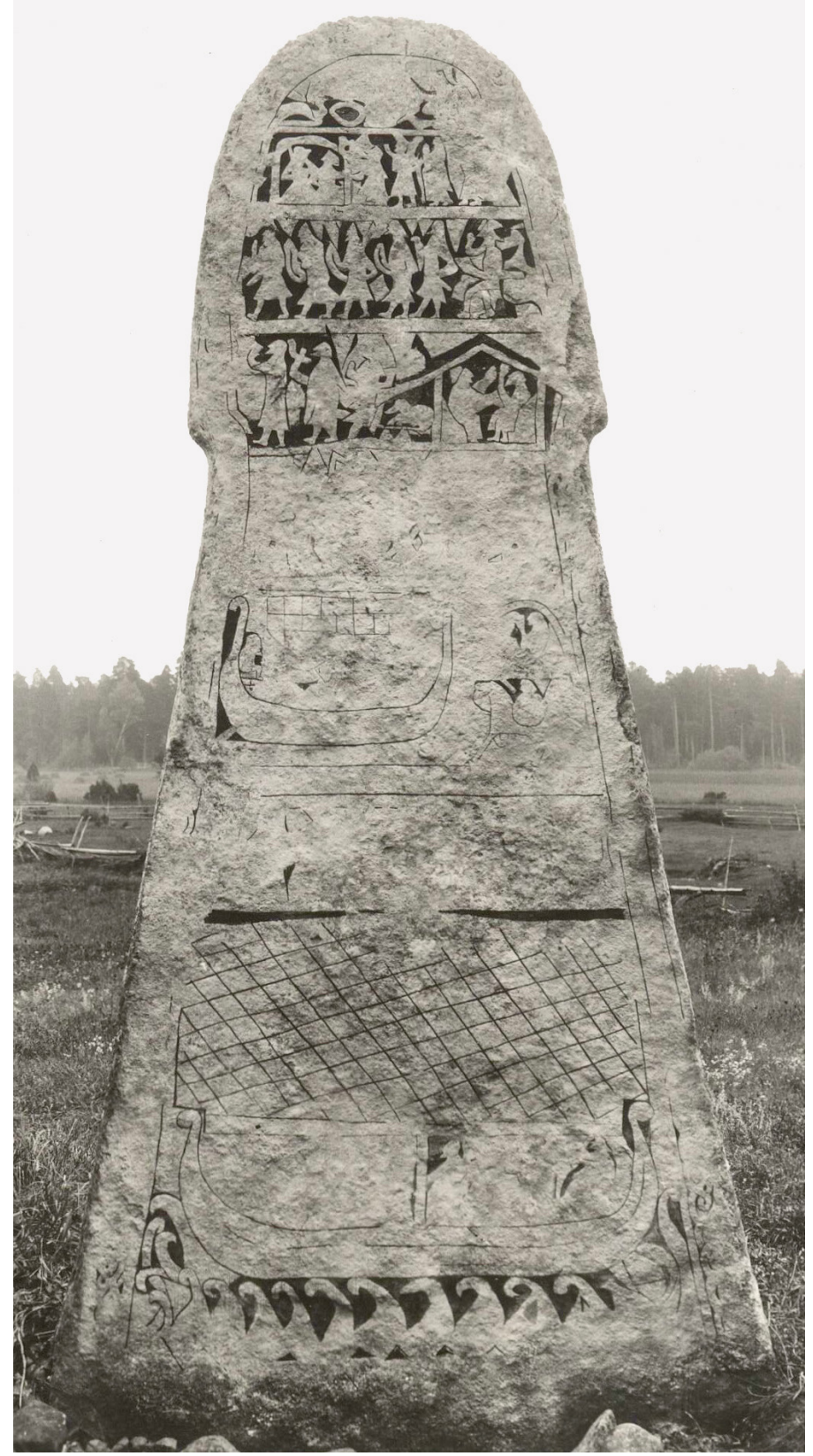

Figure 5. Buttle Änge I, painted by S. Lindqvist. Photographer: H. Faith-Ell I937. Copyright: ATA, License: CC-BY-NC-ND. 


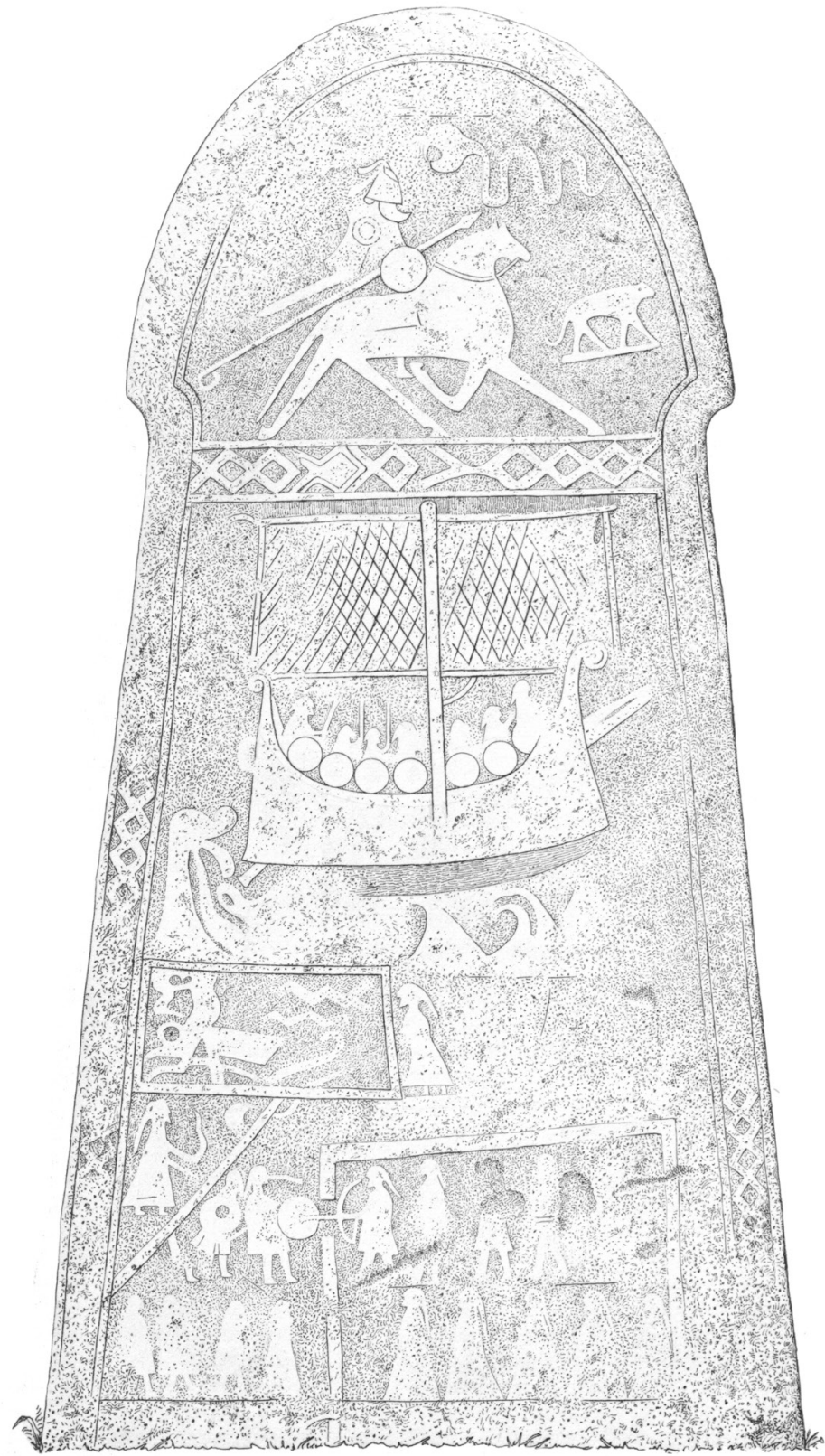

Figure 6. Klinte Hunninge I, drawing by O. Sörling (after Lindqvist I94 II 942 vol. II: fig. 428). 


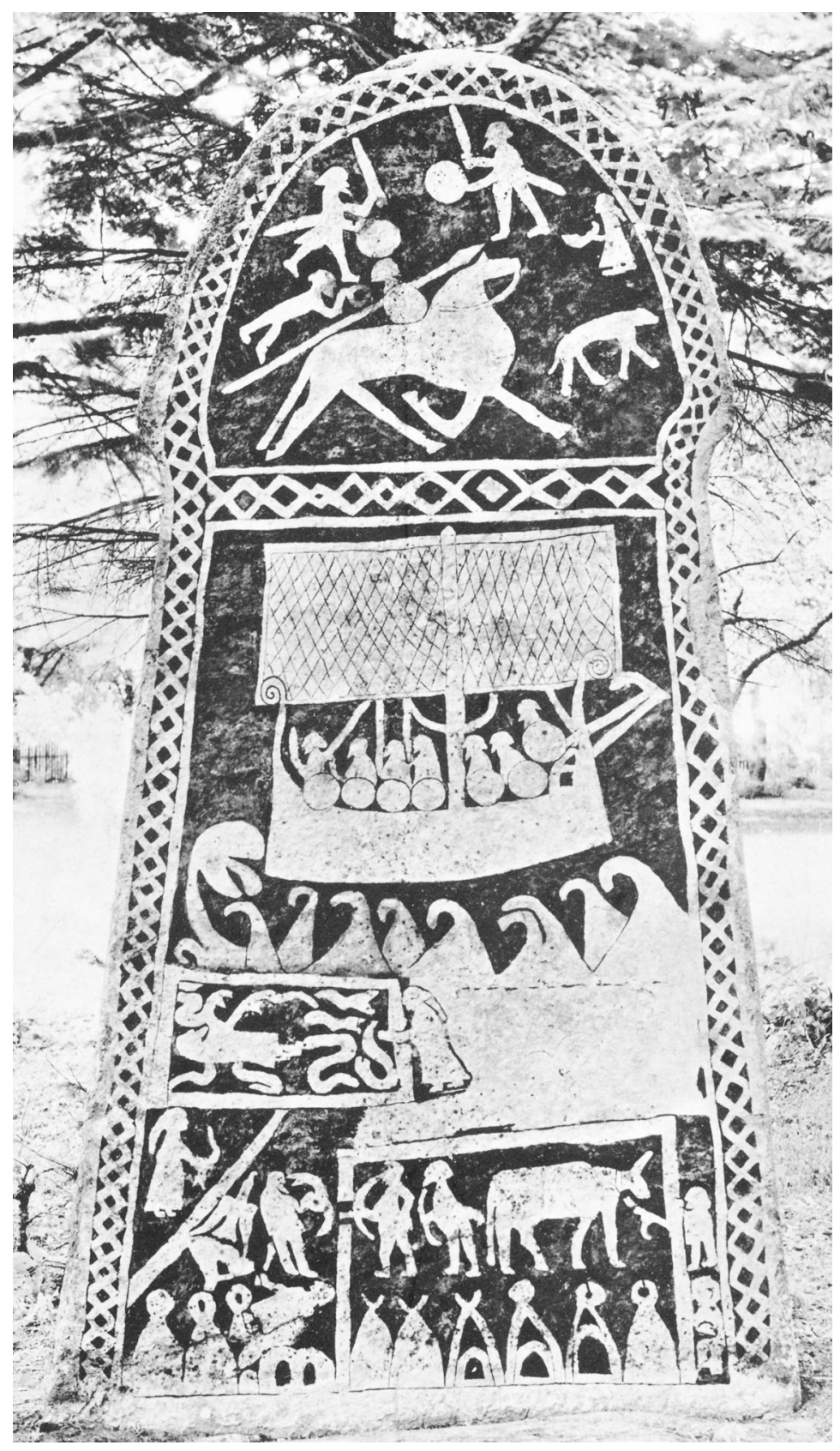

Figure 7. Klinte Hunninge I, painted by S. Lindqvist (after after Lindqvist I94I-I 942 vol. I: fig. I28). 
turned, natural stone colours as well as secondary painting can be deleted, different kinds of illumination can be simulated, details can be zoomed in on and observed from different angles and measurements can be taken.

The other technique I apply is called Reflectance Transformation Imaging (RTI). ${ }^{17}$ It was invented by Hewlett Packard and developed for archaeological and cultural heritage conservation purposes by the non-profit corporation Cultural Heritage Imaging in California. ${ }^{\mathrm{I}}$ Basically, the image capture for obtaining the digital image data from which RTI files can be produced, is performed as follows (Fig. 8-9): A sequence of images of the monument is taken with a specific set of lighting angles. Thus, the flashlight changes its position step by step after every single shot while the camera does not move. A reflective sphere, like a billiard ball, is fixed on the monument. As a result, one obtains a set of images of the same subject with different shadow impacts and with a reflection on the sphere on different positions. On this basis the RTI software creates a single high-resolution image that can be analysed on the screen, applying different rendering modes and a virtual light beam which can be controlled with a trackball (Fig. IO-II). Ultimately, this is quite a simple but rather helpful tool when it comes to detecting and documenting single details and objectifying or disproving questionable readings.

In this paper I would like to present two examples for how new surface analysis with RTI can result in completely new viewpoints and iconographic interpretations. Both examples will be discussed in more detail in my forthcoming monograph. I would like to start with the $284 \mathrm{~cm}$ high picture stone No. I from Hunninge in Klinte Parish, on the middle west coast of the island, approximately $2 \mathrm{~km}$ east of Klintehamn (type C) (Fig. 7). In the lower part of the monument a kind of rectangular enclosure is depicted (Fig. I2). Within the enclosure a man, characterized with a chin beard and typical tunic-like dress, is lying on his back, surrounded by serpents. A woman seems to reach into the enclosure.

This depiction is interpreted by most researchers as Gunnar in the snake pit. ${ }^{19}$ The story of Gunnar, King of the Gjúkungar/ Niflungar and his heroic death is mainly recorded in Volsunga saga, Snorri's Skáldskaparmál and Eddic heroic poetry, Atlamál, 


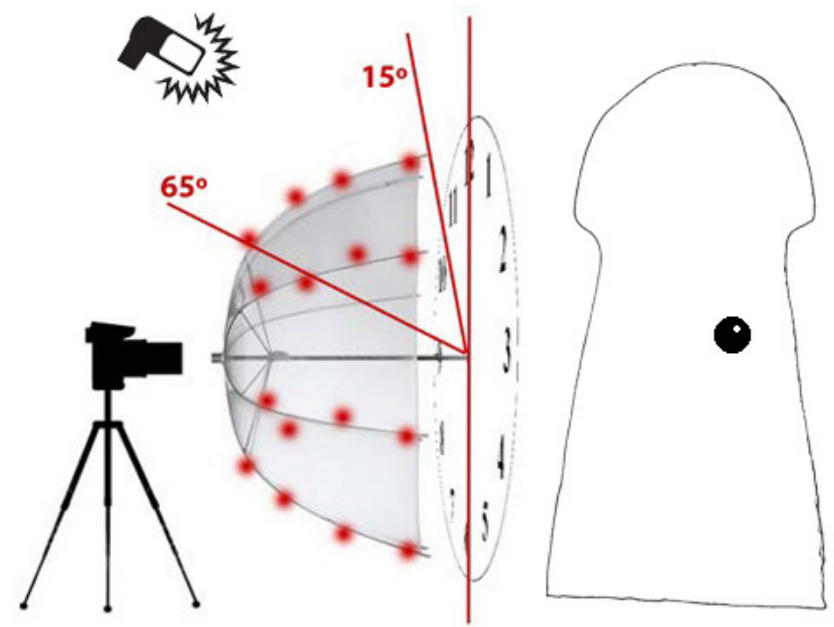

Figure 8. Image capture for RTI. Copyright: Sigmund Oehrl, License: CC-BY-NC-ND.

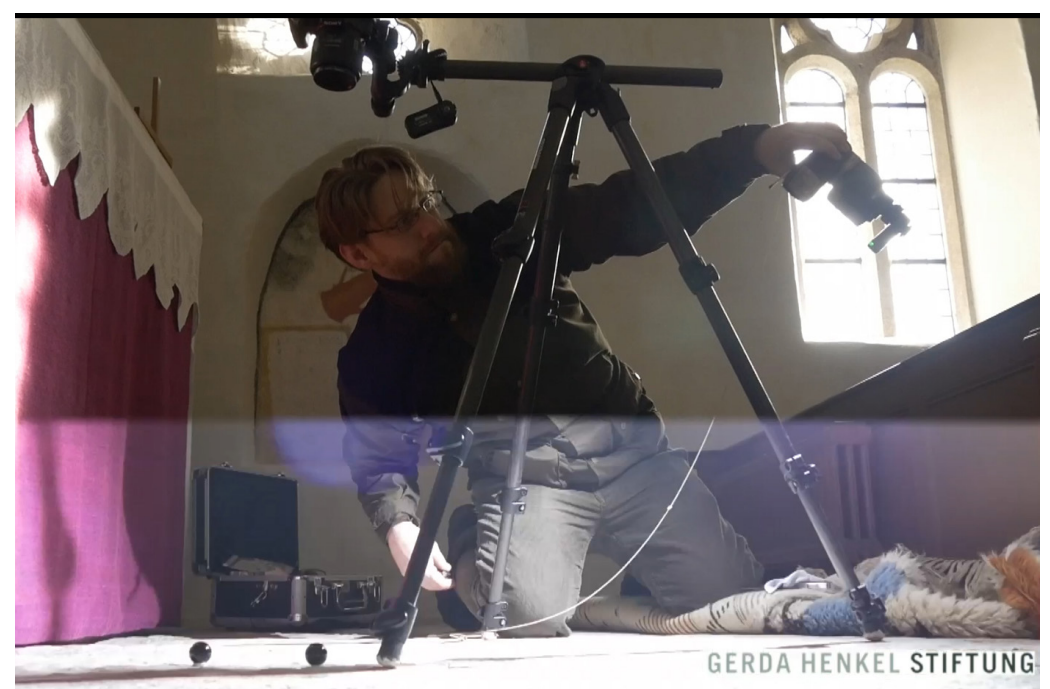

Figure 9. Image capture for RTI, Buttle Church, picture stone built into the floor in front of the altar. Photographer: P. Prestel. Copyright: Sigmund Oehrl, License: CC-BY-NC-ND. 


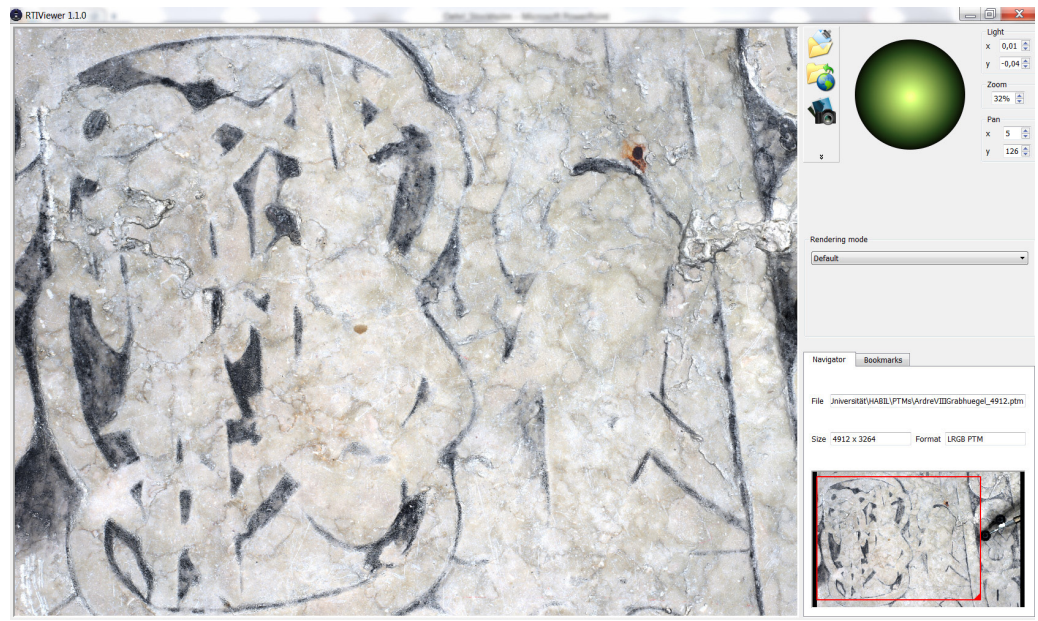

Figure 10. The RTI Viewer, showing a detail from Ardre Church VIII. Photographer: Sigmund Oehrl. Copyright: Sigmund Oehrl, License: CC-BY-NC-ND.

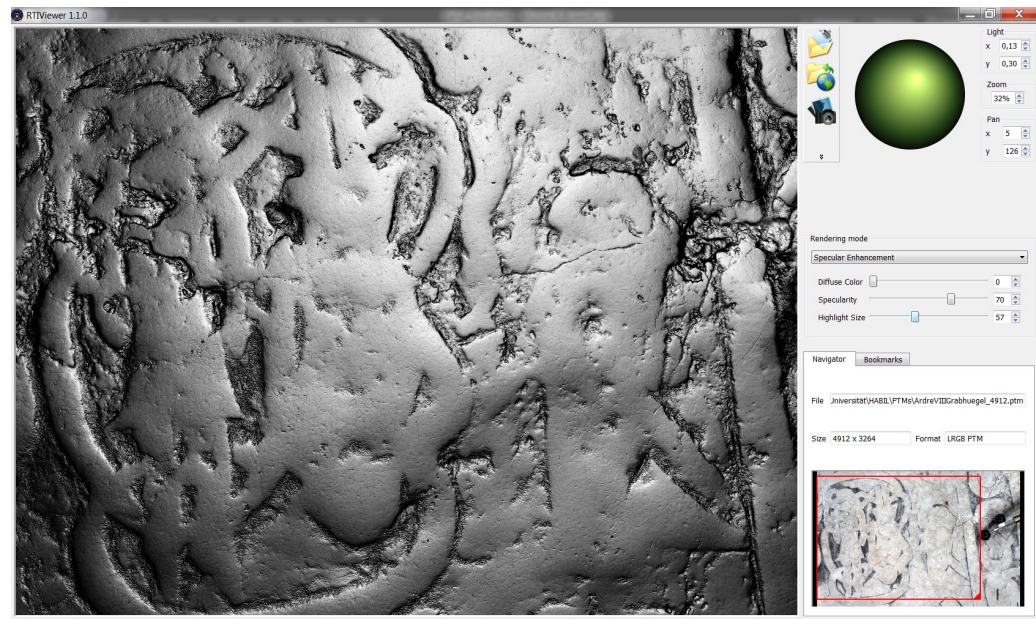

Figure 11. The RTI Viewer, showing a detail from Ardre Church VIII, analysed with rendering mode "Specular Enhancement". Photographer: Sigmund Oehrl. Copyright: Sigmund Oehrl, License: CC-BY-NC-ND. 


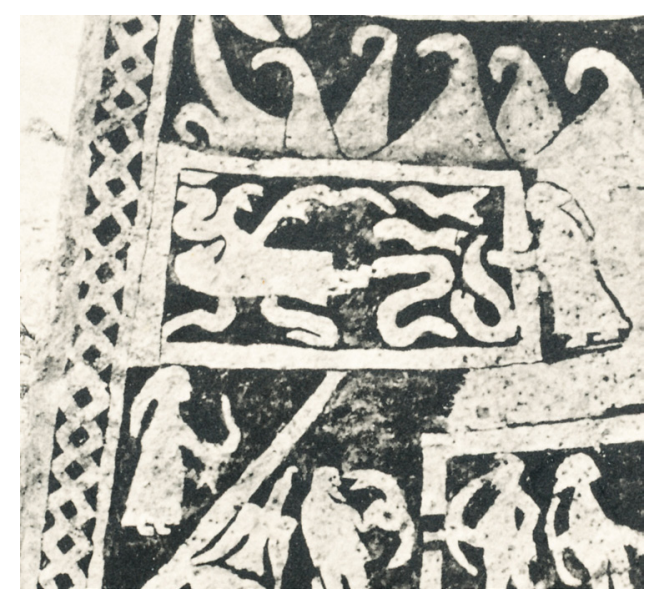

Figure 12. Detail ("snake-pit”) from Klinte Hunninge I, painted by S. Lindqvist (after spatium Lindqvist I94 I-I942 vol. I: fig. I 28).

Atlakviða, Oddrúnargrátr and Dráp Niflunga. ${ }^{\circ}$ The oldest source is Atlakviða, which is dated to the ninth or tenth century. Atli, King of the Huns and husband of Guðrún, Gunnar's sister, invites Gunnar to a feast in order to get possession of the legendary hoard of gold that Sigurðr had won from the dragon Fáfnir. Gunnar refuses to surrender the treasure or to reveal where it is hidden. $\mathrm{He}$ is put in chains and thrown into an ormgardr. There he plays the harp, brought by his sister Guðrún, in order to fend off or lull the serpents. Finally, he is killed by the animals. Although there is no harp depicted on Klinte Hunninge I, the image is interpreted on the background of this heroic narrative, the woman who reaches into the enclosure is considered to represent Guðrún, perhaps handing over the musical instrument.

As a matter of fact, the person in the enclosure depicted on Klinte Hunninge I cannot represent the Gunnar legend! By fading out Lindqvist's secondary painting of the carvings and illuminating it in the RTI Viewer, it becomes obvious that the figure has a pigtail/plait (Fig. I3-I5, turned $90^{\circ}$ to the right, so the figure is standing on its feet). According to Lindqvist's painting the figure's head, neck and back are formed by one single line. However, the RTI image clearly shows that there is another carved line, separating the figure's long hair from its body. In addition, the person's dress is a little longer and more curved than expected (train). The 


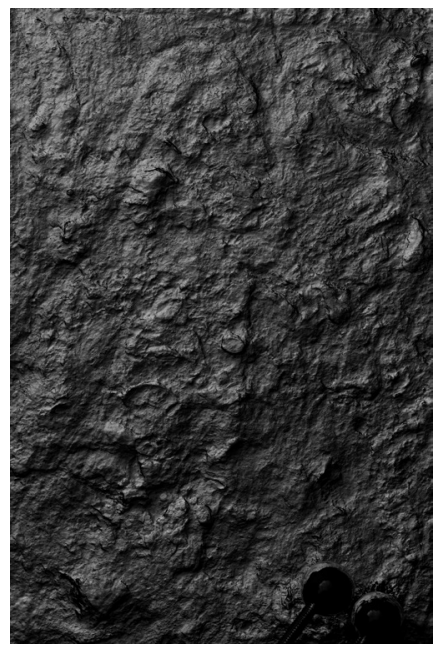

Figure 13. Klinte Hunninge I, the figure in the "snake-pit", turned $90^{\circ}$ to the right, analysed with the RTI Viewer, rendering mode "Specular Enhancement". Photographer: Sigmund Oehrl. Copyright: Sigmund Oehrl, License: CC-BY-NC-ND.

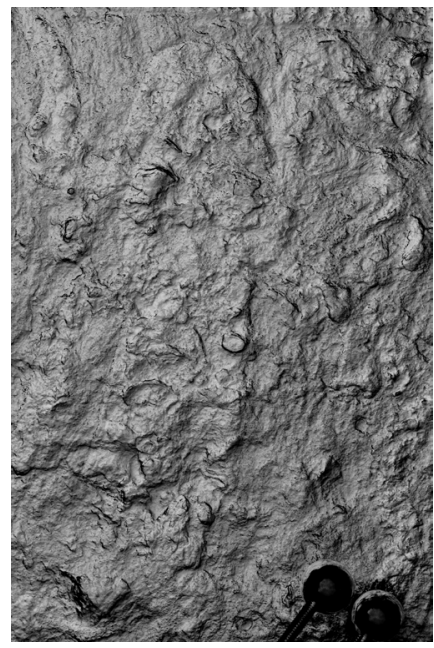

Figure 14. Klinte Hunninge I, the figure in the "snake-pit", turned $90^{\circ}$ to the right, analysed with the RTI Viewer, rendering mode "Specular Enhancement". Photographer: Sigmund Oehrl. Copyright: Sigmund Oehrl, License: CC-BY-NC-ND. 


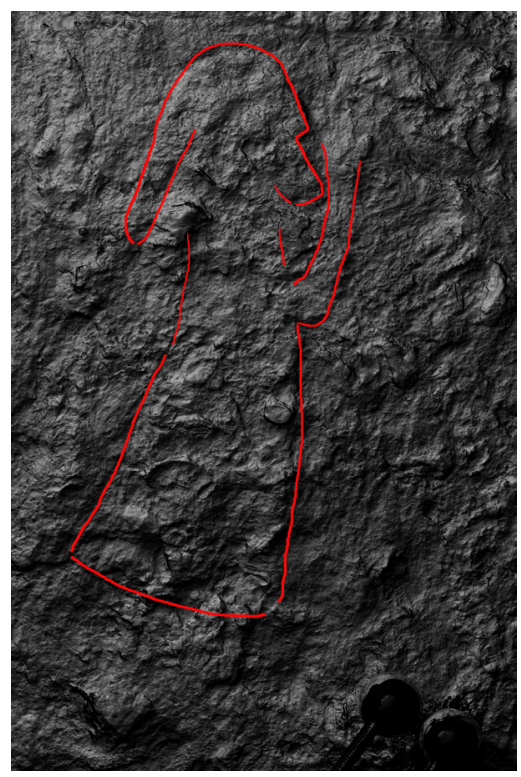

Figure 15. Klinte Hunninge I, the figure in the "snake-pit", turned $90^{\circ}$ to the right, analysed with the RTI Viewer, result. Photographer: Sigmund Oehrl. Copyright: Sigmund Oehrl, License: CC-BY-NC-ND.

upper body of the figure seems to be more slender. The supposed leg and foot cannot be verified.

Thus, the person lying in the enclosure has exactly the same gender characteristics as the female figures depicted on the same stone (Fig. I6). It is not a man but a woman in a snake pit we are dealing with. Incorrect re-painting from the early $20^{\text {th }}$ century led generations of picture stone interpreters to follow a false trail. Now, we have a totally new set of facts to base an interpretation on.

One possible interpretation could be that the snake-filled enclosure on the picture stone is influenced by Christian eschatology. To make a long story short: Swarms of serpents torturing human souls has been a widespread motif in Christian visions of hell since the $9^{\text {th }}$ century. ${ }^{2 \mathrm{I}}$ Iconographic records are also numerous, one of the earliest can be found in the Utrecht Psalter ${ }^{22}$ from 820-835 $\mathrm{AD}$ (Fig. I7)..$^{23}$ As an example from the $10^{\text {th }}$ century the BeatusApocalypse from Girona ${ }^{24}$ could be mentioned. Apparently, this 


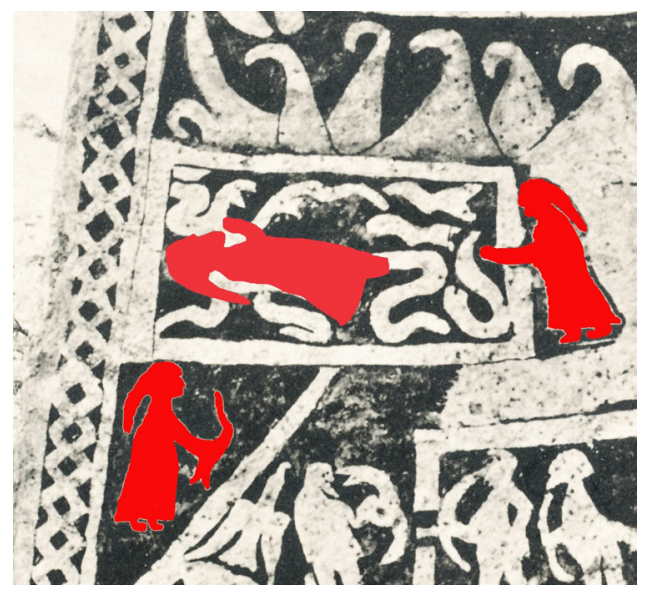

Figure 16. Klinte Hunninge I, women in and around the "snake-pit" (S. Oehrl, after Lindqvist I94 I-I942 vol. I: fig. I 28).

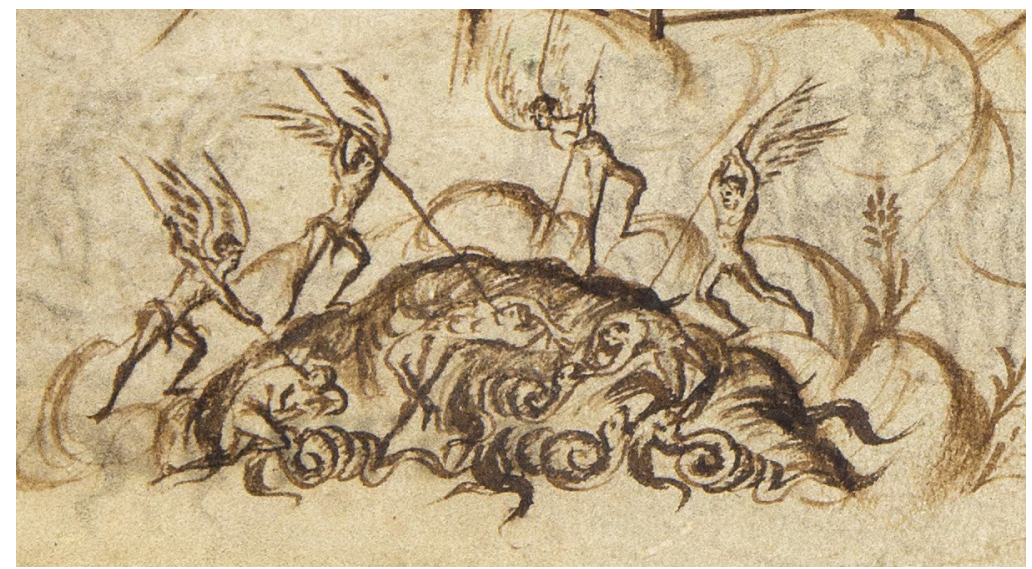

Figure 17. Utrecht Psalter, UB Utrecht Ms. 32, fol. $3 \mathrm{v}$ (after van der Horst et al. I982-I984). Copyright: UB Utrecht.

Christian idea was also borrowed by Eddic poetry: The Eddic poem Voluspá (written in the $10^{\text {th }}$ century or about the year Ioo०) contains, as most scholars agree, ${ }^{25}$ certain Christian influences. One of them seems to be the hall (salr) formed by serpents, located on the shore of the dead (Nástrondr), in which the evildoers are punished with snake venom (stanza $38-39):{ }^{26}$ 
Sal sá hon standa

Nástrondo á, fello eitrdropar

sá er undinn salr

Sá hon par vaða

menn meinsvara

oc pannz annars glepr

par saug Niðhoggr

sleit vargr vera sólo fiarri

norðr horfa dyrr;

inn um lióra,

orma hryggiom.

punga strauma

oc mordvarga,

eyrarúno;

nái framgengna,

$[\ldots] .{ }^{27}$

Such an influence, the Christian idea of a post-mortem place of punishment, can also be taken into account in the case of the woman in the snake pit depicted on the picture stone Klinte Hunninge I which probably dates to the $9^{\text {th }}$ or $10^{\text {th }}$ century.

A second possible interpretation arises from a comparison of the iconography of Klinte Hunninge I (Fig. 7) with the images on the famous, already mentioned picture stone Ardre VIII (Fig. I). Both monuments seem to be closely related. ${ }^{28}$ The Viking ship is placed in the middle of their surface, below the head of the picture stone. This is quite unusual, normally the ship is placed on the lower part of the stone. On the lowest part of both picture stones a kind of enclosure or building is depicted. Inside the building, which seems to be a cattle barn, an ox can be seen. Finally, on both monuments a human lying in an ormgarðr, a rectangular enclosure filled with snakes, is depicted, along with two female figures standing next to it. In the case of Ardre VIII there is good reason to believe that the depiction represents the punishment of Loki, according to Snorri's Gylfaginning (ch. 50):

Pá tóku Æsir parma hans ok bundu Loka með yfir pá prjá steina einn undir herðum, annarr undir lendum, priði undir knésfótum ok urðu pau bond at járni. Pá tók Skaði eitrorm ok festi upp yfir hann svá at eitrit skyldi drjúpa ór orminum i andlit honom. En Sigyn kona hans stendr hjá honom ok heldr mundlangu undir eitrdropa. En pá er full er mundlaugin pá gengr hon ok slaer út eitrinu, en meðan drýpr eitrit í andlit honom. Pá kippisk hann svá hart við at jorð oll skelfr. Pat kallið pér landskjálpta. Par liggr hann i bondum til ragnarøkrs. ${ }^{29}$

The gods capture Loki after he causes the death of Óðinn's son Baldr. He is brought into a cave and fettered by the gods. In the 
cavern the goddess Skaði takes a poisonous snake and affixes it above Loki's head in such a way that the serpent's venom drips onto his face. But Sigyn, Loki's wife, stands beside her husband and holds a bowl over his face, so the venom is caught in the bowl instead. However, when the bowl is full, Sigyn has to go and empty it. At that moment the venom can still drip onto Loki's face and the pain makes him flinch so violently that the entire earth shakes. The woman directly to the left of the serpent-filled enclosure on Ardre VIII holds the tail of one of the serpents in her hand (Fig. I 8). This could be Skaði, taking one of the serpents in order to fix it above Loki's head. $3^{\circ}$ The woman next to her is turning away from the scene holding a goblet- or bowl-like vessel in her uplifted hand. This seems to be Sigyn, emptying the bowl with the serpent's poison. ${ }^{3 \mathrm{I}}$

If this interpretation is correct (which is not beyond doubt, of course), it is likely that, in the case of Klinte Hunninge I, the figure in the serpent-filled enclosure, surrounded by two women, also represents this very myth. But why should the god Loki be

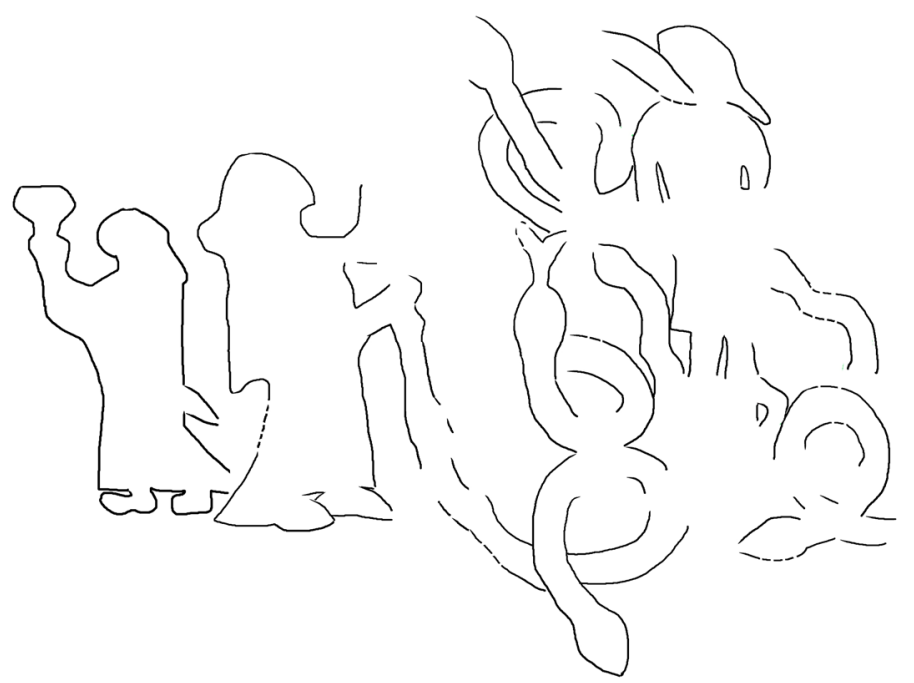

Figure 18. Loki's punishment (?) on Ardre Church VIII, drawing on basis of RTI. Photographer: Sigmund Oehrl. Copyright: Sigmund Oehrl, License: CC-BY-NC-ND. 
depicted with female attributes? Actually, according to Old Norse literary tradition, Loki features some crucial bisexual characteristics. ${ }^{32}$ In Snorri's Gylfaginning (Ch. 42) he turns into a mare in order to give birth to the horse Sleipnir. ${ }^{33} \mathrm{He}$ also turns into a woman before he talks to Baldr's mother Frigg in order to find out, how Baldr can be injured (Ch. 49). ${ }^{34}$ In the shape of a giantess he refuses to grieve for Baldr. ${ }^{35}$ According to Lokasenna (stanza $23,33)^{36}$ Loki gave birth to children and according to Hyndluljóð (stanza $4 \mathrm{I})^{37}$ he became pregnant after eating a roasted heart. Is it imaginable, against this very background, that in Viking art Loki can be depicted with female attributes? In fact, this actually seems to be the case on the famous Anglo-Scandinavian stone cross from Gosforth in Cumbria (Northumbria), erected in the first half of the $10^{\text {th }}$ century (Fig. I9)..$^{8}$ It depicts Loki lying on his back, his legs, arms and neck fettered, a serpent's head in front of his face and Sigyn sitting on a chair, holding a crescent-shaped bowl in her outstretched hand. There is absolutely no doubt, that this is a depiction of Loki's punishment (incorporated into a Christian

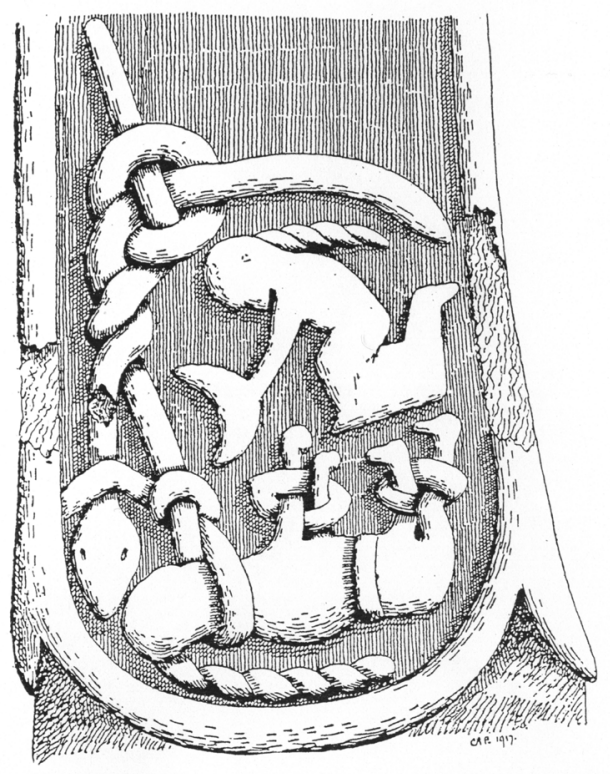

Figure 19. Loki's punishment on the Gosforth Cross (West side), drawing by C. A. Parker (after Collingwood/Parker I9I7: Fig 4). 


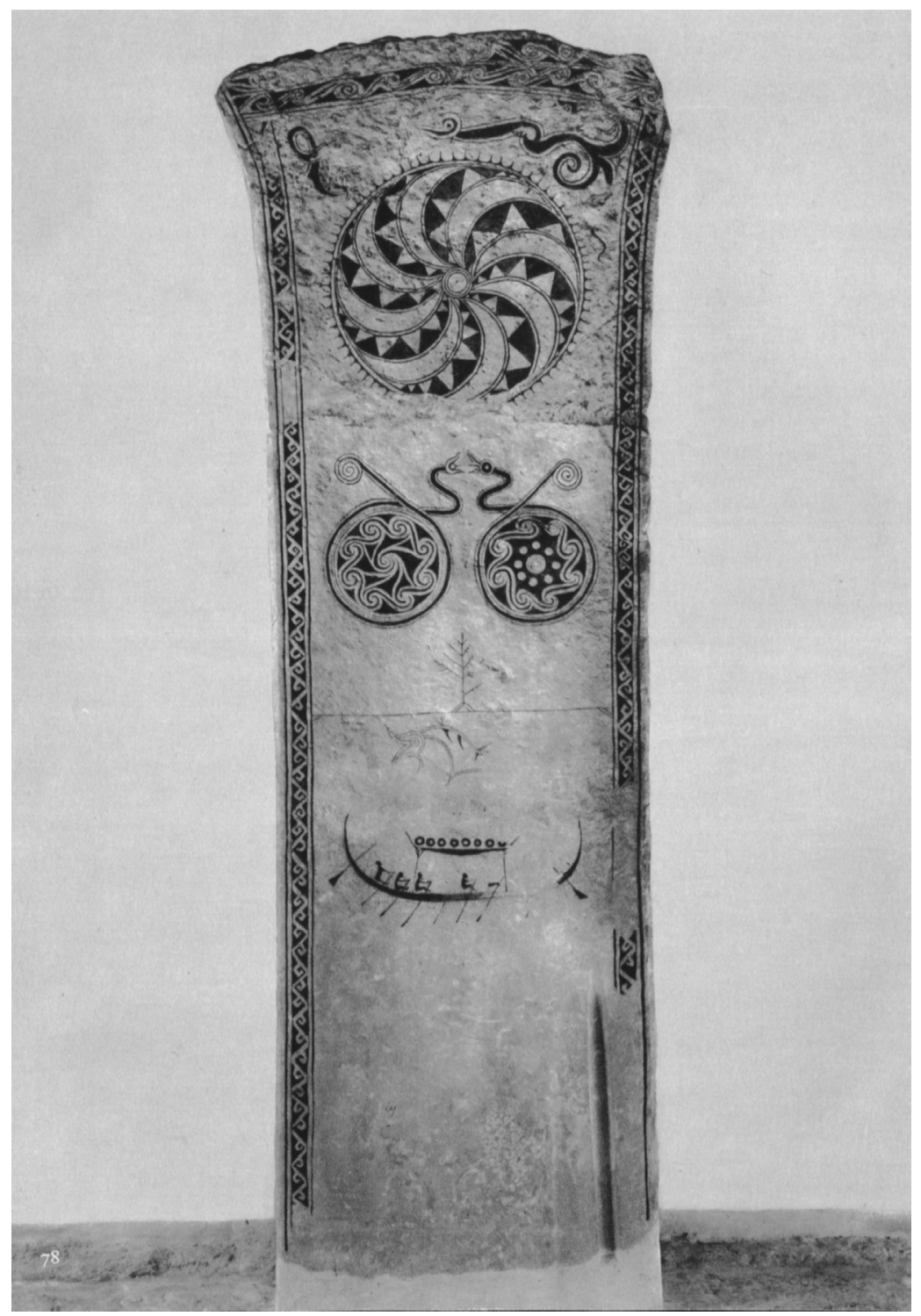

Figure 20. Sanda Church IV, painted by Lindqvist (after Andersson I968: Table 78). 
context). ${ }^{39}$ The fettered god is presented here with a braid, exactly the same hairstyle that characterizes his wife. No other male figure on the cross has a similar hairstyle. It is a reasonable assumption that the woman in the ormgardr on Klinte Hunninge I also represents the god Loki in the snake-filled cavern. Thus, the two women surrounding the enclosure could also be interpreted. As suggested for the figures on Ardre VIII, they could be regarded as Skaði (below), holding a serpent in her hand and Sigyn (to the right), approaching with the bowl, handing it into the room.

The second monument I would like to present is picture stone No. IV from Sanda Church, about $4 \mathrm{~km}$ northeast of Klintehamn..$^{\circ}$ The $330 \mathrm{~cm}$-high stone slab dates to the Migration Period, probably to the $6^{\text {th }}$ century AD (type A). In Lindqvist's book only the upper half of the monument is shown, ${ }^{4 \mathrm{I}}$ the lower one was found in 1956 , beneath the church floor. Lindqvist painted and published the entire stone in 1962 (Fig. 20-2I). $4^{2}$ According to the published painting, a carved horizontal line divides the stone into two halves. In the upper half a big disk with a whirl motif can be

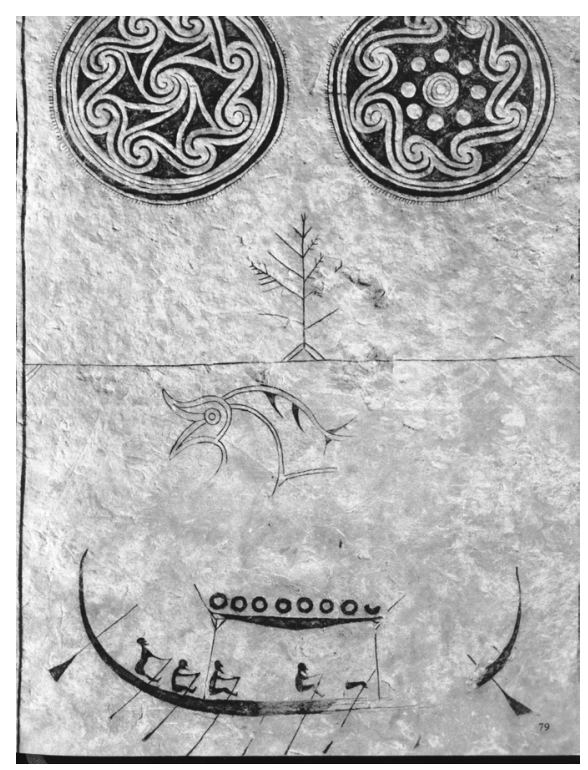

Figure 21. Sanda Church IV, lower part, painted by Lindqvist (after Andersson I968: Table 79). 
seen, as well as a pair of two smaller discs, encircled by serpents. A simplified tree is standing on the horizontal line. Beneath the line the forepart of an animal with open jaws can be seen, as well as a rowing boat with crew. However, my RTI analysis has revealed that there are remains of some more carvings on the stone, in particular in front of the animal. A relatively deep carved line can easily be seen. Some more grooves to the right of this line and a clearly carved plane beneath these grooves can be assembled into a horseman with a spear in his hand (Fig. 22-23). A very similar horseman with bent arm and a spear in his uplifted hand can be seen on picture stone No. I from Martebo Church (Fig. 24).43

Obviously, the Sanda horseman is fighting against the animal, probably a beast of prey, a lion-like creature or a kind of dragon. Against this background the depictions of a man in front of a millipede-like creature on Hangvar Austers I (Fig. 25) ) $^{44}$ and two armed horsemen flanking the serpent that encircles the whirl discs on Martebo Church I (Fig. 24) should also be interpreted

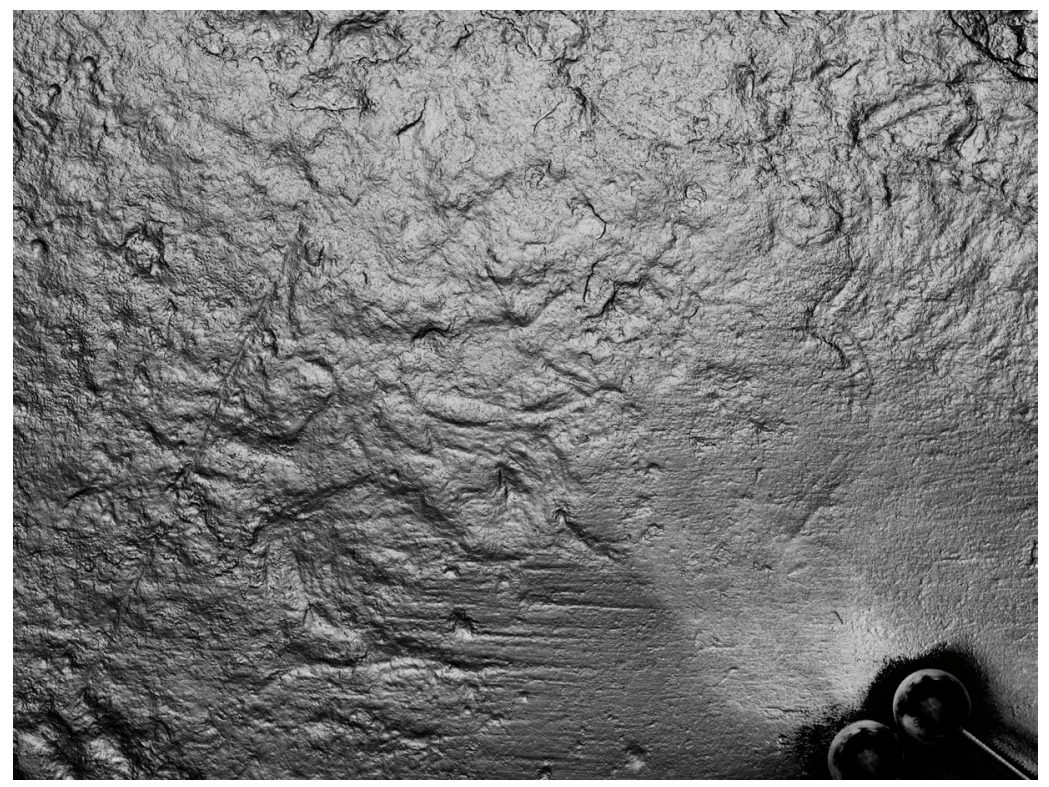

Figure 22. Sanda Church IV, equestrian, analyzed with the RTI Viewer, rendering mode "Specular Enhancement". Photographer: Sigmund Oehrl. Copyright: Sigmund Oehrl, License: CC-BY-NC-ND. 


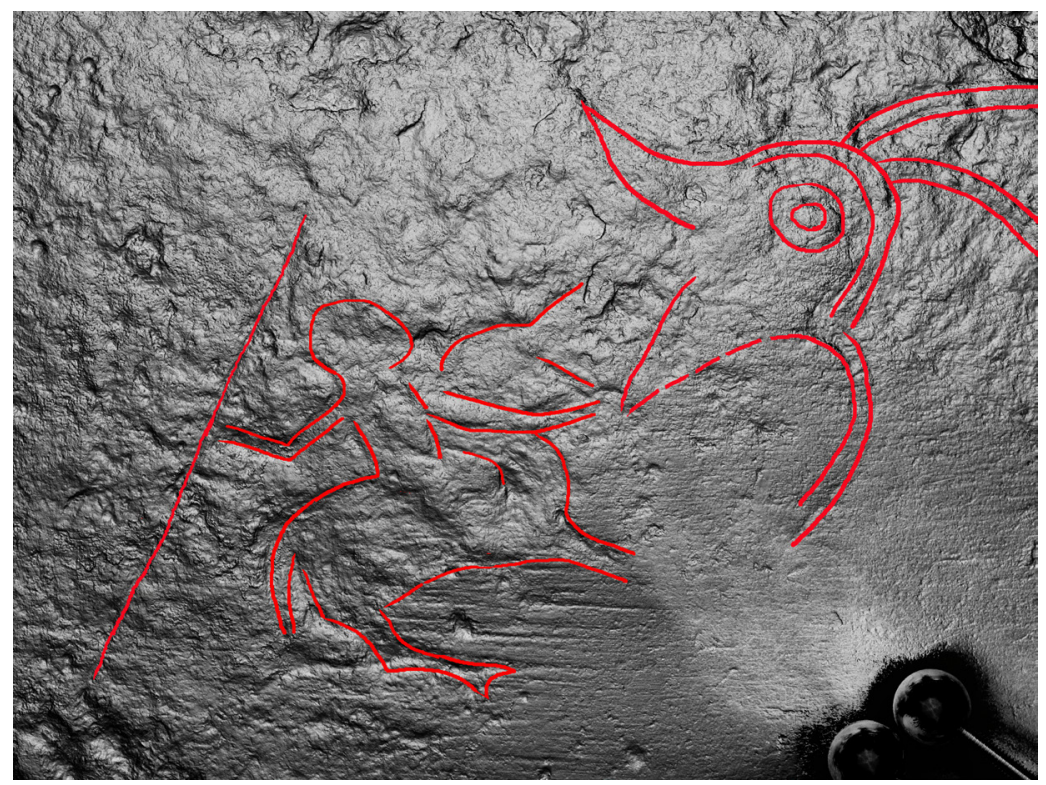

Figure 23. Sanda Church IV, equestrian, analysed with the RTI Viewer, result. Photographer: Sigmund Oehrl. Copyright: Sigmund Oehrl, License: CC-BY-NC-ND.

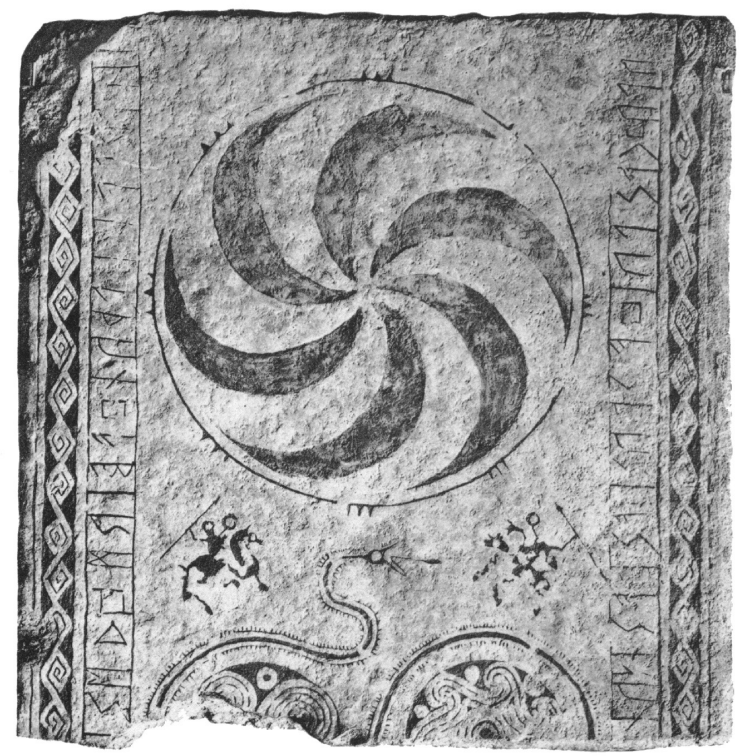

Figure 24. Martebo Church I (after Lindqvist I94I-I942 vol. I: Fig. 6). 


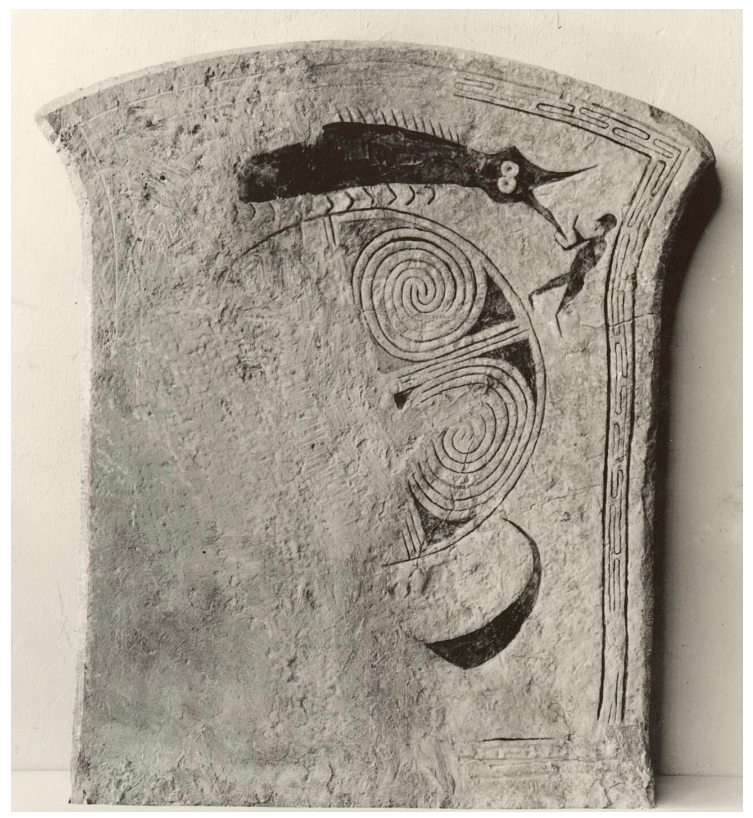

Figure 25. Hangvar Austers I. Photographer: H. Faith-Ell I937. Copyright: ATA, License: CC-BY-NC-ND.

as combat situations. Thus, a warrior fighting an animal seems to be one of the most important topics in the iconography of the Migration Period picture stones. Nevertheless, the equestrian defeating a serpent- or dragon-like enemy is a rarely documented motif in early Germanic art. Two parallels will be mentioned: the equestrian with spear and sword on the gold bracteate IK 65 Gudbrandsdalen-C (Fig. 26) 45 in Norway (Oppland) who seems to be struggling with a group of animals, defeating a kind of large reptile (late $5^{\text {th }}$ century) ${ }^{46}$ and the famous helmet plate from Vendel

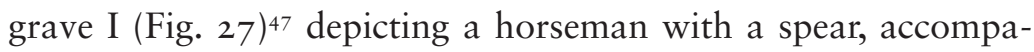
nied by two birds, riding down a snake ( 2 nd half $7^{\text {th }}$ century)..$^{8}$

As Wilhelm Holmqvist has already noted, ${ }^{49}$ both images seem to be influenced by Christian rider motifs. The iconography of the Equestrian Saints arises from eastern Mediterranean art. Mainly Coptic depictions of mounted Warrior Saints, defeating lions or serpent-like demons were the models for a group of images of victorious equestrians from the Merovingian Period, in particular 


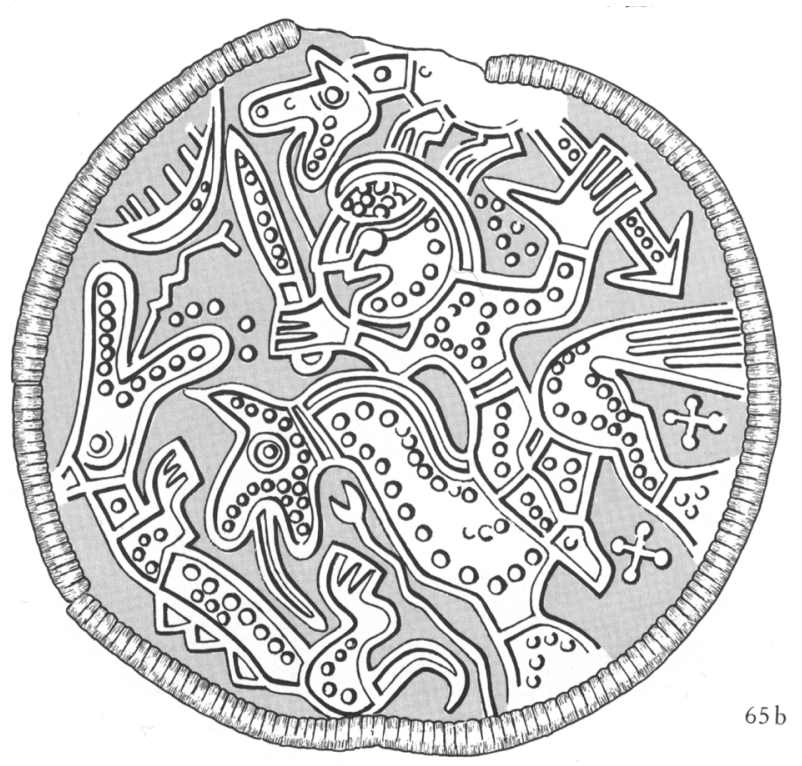

Figure 26. Gold bracteate IK 65 Gudbrandsdalen-C (after Hauck et al. I985-I989: Taf. 78).

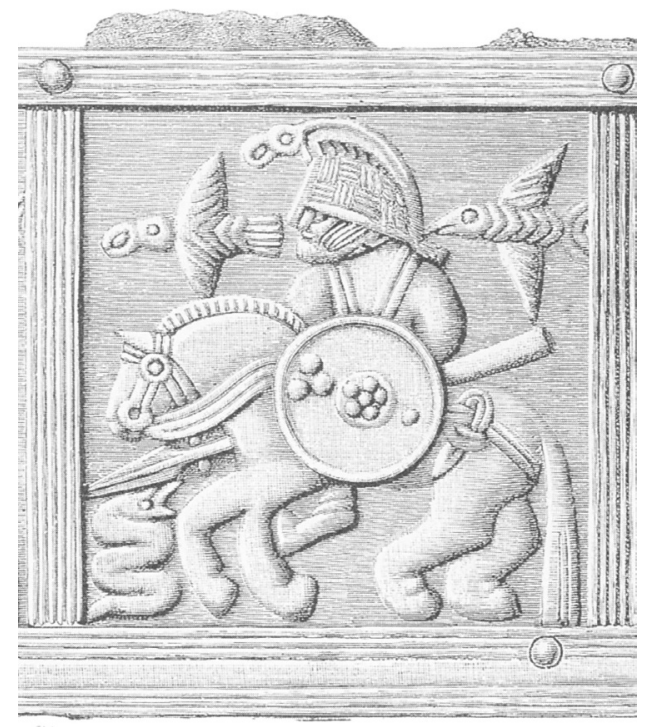

Figure 27. Helmet plate from Vendel I (drawing after Stolpe/Arne I9I 2: Taf. VI,I). 


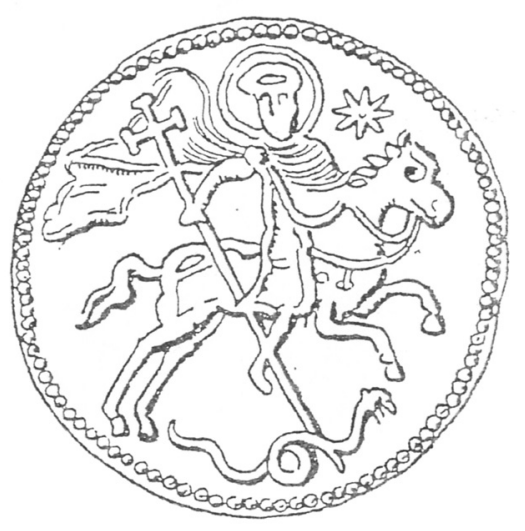

Figure 28. Equestrian Saint on a Mediterranean amulet found in Strasbourg (drawing after Fingerlin 2010: Abb. I6).

on press plate medallions (Fig. 28). ${ }^{50}$ Roman coins with depictions of the Christian emperor, riding on horseback and killing a snake with a spear, should also be mentioned here (Fig. 29). ${ }^{5 \mathrm{I}} \mathrm{I}$ assume that the warrior on horseback fighting the beast on Sanda Church IV (as well as Martebo Church I) is also influenced by Christian depictions like these. However, I do not believe that the Gotlandic stone carver intended to depict a Christian saint or the Roman emperor. It is more likely, following Holmqvist's view, ${ }^{52}$ that he borrowed the motif from continental (or directly from Mediterranean) art and re-interpreted it, against the background of indigenous tradition.

Who the horseman and his enemy are, is difficult or even impossible to say. However, there are some observations to be made which give us more insight into the context of the combat. The figures are placed beneath the horizontal line with the tree. Thus, they are clearly located in an area under the earth. This interpretation is supported by the fact that the discs on the early Gotlandic picture stones, occasionally encircled by serpents, are commonly regarded as celestial bodies, representing cosmological concepts. ${ }^{53}$ This interpretation is well reasoned: on the suggested models for the early Gotlandic picture stones, sepulchral stones from the Roman provinces, exactly the same whirl discs occur, among depictions of stars and the half moon. ${ }^{54}$ The motif 


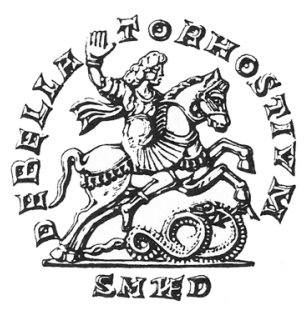

Figure 29. Gold medallion of Constantius II. (337-36I) (drawing after Vierck I98I: Abb. 5.5).

of a cosmic, world-encircling serpent is not only recorded in Old Norse religion (Miðgarðsormr) but likewise in Christian, first and foremost in eastern Mediterranean, Egyptian-Coptic tradition. ${ }^{55}$ Last but not least the edges of many of these discs on Gotlandic picture stones are decorated with short lines or spikes looking like a kind of corona, possibly the rays of the sun. ${ }^{56}$ As a result, the Sanda monument is divided into two cosmological spheres, the world above and the world below. The combat between the equestrian and the beast is located in an underworld. This observation goes well with the common interpretation of the rowing boat on the early picture stones of Gotland, which is regarded as the vessel that carries the dead to a transmarine world of death. ${ }^{57}$

Whether the tiny tree indicating the border between the two cosmological spheres could therefore be regarded as a kind of world tree and whether there is any connection to the world tree Yggdrasill, documented in Eddic poetry, remains uncertain. The beast directly beneath the roots of the tree could, against this background, be reminiscent of the dragon Niðhoggr who, according to Grimnismál stanza $35,{ }^{8}$ is sitting under the world tree, gnawing at its roots. In Voluspá stanza 39 Niðhoggr is devouring the corpses of the dead on the shore of the netherworld (Nástrondr). ${ }^{59}$ Although there are four or even five centuries in between, it does not seem unlikely that the picture stone Sanda Church IV reflects ideas of the cosmos and the world of the dead comparable to those preserved in Old Norse literature. Nevertheless, the identity of the warrior who dares to compete against the demon of death remains enigmatic. ${ }^{60}$ 
As can be seen from the examples discussed above, the use of digital methods such as RTI and ${ }_{3} \mathrm{D}$-modelling permits a more objective documentation of the Gotland picture stones and allows re-readings that lead to entirely new interpretations, broadening our knowledge of Germanic religion and heroic legend. It should be the aim of future picture stone research to test and establish such more objective methods and, on this basis, provide a comprehensive re-edition of this unique and highly valuable source material.

\section{Notes}

I. The basic works are the edition Lindqvist I94I-I942, the little handbook Lamm \& Nylén 2003 and the contributions in the conference volume Herlin Karnell et al. 20 2, documenting the current state of research. See in addition Oehrl 20I 5; 20I 7 b. A good overview about the status of research is also provided by Helmbrecht (20II:272-28I). I would also like to mention the monographs Buisson (I976) about the prominent stone VIII from Ardre Church and Althaus (1993) as well as the unpublished works of Eshleman (I983) and Böttger-Niedenzu (I982). Guber's book (201 I) about the early picture stones on Gotland (Type A and B) offers a helpful overview about the known material and common interpretations but does not lead to completely new insights (cf. Oehrl 20I3a). The group of late Viking Rune stones (Type E) is investigated by Westphal (2004).

2. Lindqvist I94I-I942 vol. I:9I-93 and Fig. 238, 239; Holmqvist I952.

3. Lindqvist I94 I-I942 vol. I: I77ff.

4. Concerning this discussion see esp. Eshleman 1983:307-308; Hyenstrand I989:3 I; Varenius I992:52, 82; Wilson I995:64; I998; Imer 200I; 20I2; Herlin Karnell et al. 20I 2:7, I4-I 5.

5. Lindqvist I94I-I942 vol. I: Fig. I37-I3 8; vol. II:I 5-I7, Fig. 305306; Lamm \& Nylén 2003: Nr. 4.

6. Lindqvist I94I-I942 vol. I: Fig. I39-I40; vol. II:22-24, Fig. 3 I I; Lamm \& Nylén 2003: Nr. I6.

7. Esp. Gylfaginning ch. 42, in Faulkes 2005:34-35. 
8. About the iconography of Wayland the Smith see esp. Nedoma I988 (concerning Ardre VII see p. 27-3I) and elaborately Oehrl 20I 2b (concerning Ardre VIII see p. 284-287) with bibliography. See also the relevant work Buisson I976:70-80.

9. Neckel/Kuhn I983:I I6-I23.

Iо. Nedoma I988:I I6.

II. The find was already published and discussed in Zeitschrift für deutsches Altertum und deutsche Literatur (Oehrl 20I7a). For a preliminary report see Oehrl 2016.

I2. Beck I964:3 I-45; Hauck I954:4I-42; I957:6-7; I978:42-44; I980:246-274; I981:203-256; I982:346-349; I983a:595-599; I983b:453-457; I994:222-223. Concerning the concept of the divine helper in battle more generally, in biblical, antique and medieval tradition, see Graus 1977; Schreiner 2000; 2004.

I3. See Beck I964:3 I-45.

I4. Concerning these basic problems see Oehrl 20I2a, 20I5 and $20 \mathrm{I} 7 \mathrm{~b}$ with further literature and examples, as well as Kitzler Åhfeldt 20I 5:407-408.

I 5. Even Lindqvist himself was actually aware of this problem (I94I-I942 vol. I:I 2-I 5).

16. Laila Kitzler Åhfeldt analyzed 3D-models of rune stones and picture stones, using a high-resolution portable optical ${ }_{3} \mathrm{D}$ scanner (ATOS II from GOM), in order to investigate carving techniques and the use of templates (Kitzler Åhfeldt 2009; 20I 2; 20I3; 20I 5); concerning the benefits of this method in terms of iconography see Oehrl 2OI 2a:IO3-IO4; 20I2b:302-303, Fig. I6; 20I 5:225, 232, Fig. 37-40. I7. I conducted my RTI analysis of picture stones on Gotland and in Stockholm between April and September 20I3. The project was financed by DAAD, Fritz Thyssen Stiftung and Gerda Henkel Stiftung. Preliminary information about my research are published in Oehrl 201 5:233 and Oehrl 2017b. See also Andreeff \& Potter 20I4.

I 8.http://culturalheritageimaging.org/Technologies/RTI/(I9.IO.20I 5). On the CHI web page there is also a list of publications about RTI. 
19. To name only a few of them: von See I98 I:I I 8; Althaus 1993:204; Reichert 2003:33; Lamm \& Nylén 2003:52; Oehrl 2006:I09; Staecker 2006:365; Heinzle 20I0:24; Aðalheiður Guðmundsdóttir 20I 2:I032ff. and 20I 5:359-360.

20. The written and the iconographic sources are gathered and discussed in Aðalheiður Guðmundsdóttir 2012 and 2015; Blindheim I972-1973; I973:2 I-23; Margeson 1980; von See et al. 2009:914, 928; Oehrl 2006:107-IIO.

2I.Seefor instance Nordland I949:93-I00;Krappe I940-I94 I:29-32.

22. UB Utrecht Ms. 32, fol. $3 \mathrm{v}$ and 59r.

23. Facsimile and commentary: van der Horst et al. I982-I984.

24. Archivo Capitular de Girona ms. 7 olim 4I, fol. I7v. Williams I994-2003 vol. I: pl. 23; vol. 2:56-57, Ill. 290.

25. Bang I879; Bugge I88I-I889; Meyer I889; Olrik I922:I3 I and passim; Heusler I94I:I90; Sigurður Nordal I980:I33-I40; Hultgård I990:353; Dronke I992; McKinnell I994:I20-I27; Dronke I997:93-I04; North 2003; McKinnell 2008; Horst 2010:239-249; concerning the current state of discussion see the contributions in the conference volume The Nordic Apocalypse: Steinsland 20I3; Johansson 20I3; Pétur Pétursson 20I3; Samplonius 20I3; Kure 20I3.

26. See Kure 2013 with a critical point of view.

27. Neckel/Kuhn I983:9. Cf. Gylfaginning ch. 52, in Faulkes 2005:53. Translation: "A hall she saw standing far from the sun, on Corpsestrand; its doors look north; poison-drops fall in through the roofvents, the hall is woven of serpent's spines. There she saw wading in turbid streams false-oaths swearers and murderers, and the seducer of another man's close confidante; there Nidhogg sucks the corpses of the dead - a wolf tears at men [...]" (Larrington 2014:9).

28. Böttger-Niedenzu I982:69; Oehrl 2009:548.

29. Faulkes 2005:49. Translation: "Then Skadi got a poisonous snake and fixed it up over him so that the poison would drip from the snake into his face. But his wife Sigyn stands next to him holding a basin 
under the drops of poison. And when the basin is full she goes and pours away the poison, but in the meantime the poison drips into his face. Then he jerks away so hard that the whole earth shakes. That is what you call an earthquake. There he will lie in bonds until Ragnarok" (Faulkes I989, 52).

30. Buisson 1976:65-66.

3 I. Lindqvist I94I-I942 vol. I:96. Lindqvist beliefs, however, that both women represent Sigyn, holding the vessel.

32. See for instance de Vries I933:21 5-223; Ström 1956:69-73; Mundal I998-2000; North 200I.

33. Faulkes 2005:34-35.

34. Faulkes 2005:45.

35. Faulkes 2005:48.

36. Neckel/Kuhn I983:IOI, I03.

37. Neckel/Kuhn I983:294.

38. Bailey \& Cramp I988:I02-I03, Ill. $288 \mathrm{ff}$.

39. Calverley I 883:378-38 I; Stephens I 884:20-2 I; Bugge I 899:262; Olrik I922:I2; Reitzenstein I924:46; Shetelig I933:223; Ellis Davidson I950:I30; Bailey I980:I28; Lang I989; Bailey I996:8788; Haavardsholm I996:I24-I27 (critical); Bailey 2003:2I; Fuglesang 2004:219-220; Bailey \& Cramp I988:102-I03; Kopár 2OI2:90-IOI.

40. Lamm \& Nylén 2003: Nr. 2 I 5.

4I. Lindqvist I94 I-I 942 vol. II:I Io, Fig. 48 I.

42. Lindqvist 1962.

43. Lindqvist I94I-I942 vol. I: Fig. 6; vol. II:I00-IO2, Fig. 462; Lamm \& Nylén 2003: Nr. I94.

44. Lindqvist I94I-I942 vol. I: Fig. 27; vol. II:69, Fig. 403-404; Lamm \& Nylén 2003: Nr. I 26.

45. Hauck et al. I985-I989:I2 I, Taf. 77-78. 
46. Concerning its interpretation see in particular Ellmers ( $1970: 2$ I $7 \mathrm{ff}$.), who tries to connect the depiction with the battle of Ragnarøk, and Hauck (1983b:439), who regards the rider as a Dioscuric deity and divine helper against demons (see below en. 59).

47. Helmbrecht 20II: Kat. Nr. I090, Abb. 6g, I If-g, quoting the relevant literature.

48. The rider was often interpreted as Óðinn, accompanied by his two ravens. The snake, however, is difficult to include (see esp. Beck I964:9-I2, I9-3I).

49. Holmqvist I939: I Ioff., 270-27 I.

50. See esp. (with illustrations) Holmqvist I939: I Ioff.; Böhner I982:I03ff.; Quast 2002:269, 275; 2009; Fingerlin 2010:42-46.

5I. Holmqvist I939:275; Beck I964:23-25.

52. Holmqvist I939:22 I and passim.

53. The depictions on early Gotlandic picture stone, first and foremost on Sanda Church IV, were interpreted as cosmological concepts esp. by Ellmers (I98I; I986:342-350); Hauck (I983a); Ellis Davidsson (I969:I40-I45; I988:I68-I70); Althaus (I993:77-84, 97-98, I47I49) and Andrén, who connects the images with the iconography of the Bronze Age (20I2). Cf. already Lindqvist I94 I-I 942 vol. I:9 I-92. 54. Lindqvist I94 I-I942 vol. I:9 I-93 and Fig. 23 8, 239; cf. Cumont I942, esp. Fig. 54-59.

55. Oehrl 20I3b; 20I4; Ellmers (I98 I:36ff.; I986:342ff.) interprets the two discs encircled by serpents as depictions of Miðgarðr and the netherworld (Hel), Hauck (I983a:546-547, 578-579) regards both of them as postmortem places of punishment.

56. Lamm \& Nylén 2003:20; Guber 20I I:44-47.

57. The literal, iconographic and archaeological references to the idea of a transmarine world of the dead and the afterlife journey by boat in Germanic tradition are collected and discussed in detail by Egeler 2OI5:II3-I 80 . Concerning the boat on the early picture stones of Gotland see in particular Hauck I983a:546, 577.

58. Neckel/Kuhn I983:64. 
59. Neckel/Kuhn I983:9.

60. The pairs of warriors and horses on the early Gotlandic picture stones are interpreted by Hauck (I983a) as Dioscuri, fighting against demons of death and protecting the dead on their way through the afterworld. Helmet plates of the Merovingian Period and Migration Period gold bracteates are also included in Hauck's comprehensive reconstruction of ancient Germanic Dioscuri (to name just a few more of his articles: Hauck I980, esp. 264ff.; I983b; I984; I994:208242). The results of my re-analysis of Sanda Church IV could actually be interpreted against this very background. The equestrian could, following Hauck's idea, represent such a divine helper in need, struggling with a demon in the underworld. However, Hauck's results remain hypothetical to me. Nevertheless, his study has to be regarded as the most extensive and best-founded investigation of the iconography of early Gotlandic picture stones. Hauck's far-sighted consideration of Mediterranean parallels and his power of observation (as well as his imagination) are still unmatched.

\section{References}

\section{Primary Sources}

Gylfaginning. Faulkes, Anthony (ed.). 2005. Edda I. Prologue and Gylfaginning. Second edition. Oxford: Viking Society for Northern Research.

- Faulkes, Anthony. 1987. Edda. Snorri Sturluson. Translated from the Icelandic and introduced by Anthony Faulkes. Everyman's library, No. 499. London.

Edda. Neckel, Gustav \& Kuhn, Hans (ed.). 1983.Edda. Die Lieder des Codex Regius nebst verwandten Denkmälern I: Text. Germanische Bibliothek. 4. Reihe: Texte. Fifth Edition. Heidelberg: Winter.

_Larrington, Carolyne. 20 I4. The Poetic Edda. Second edition. Oxford World's Classics. Oxford: Oxford University Press.

Secondary Literature

Aðalheiður Guðmundsdóttir. 20I2. Gunnar and the Snake Pit in Medieval Art and Legend. In Speculum, vol. 87:4, IO I 5-IO49. 
Aðalheiður Guðmundsdóttir. 20I 5. Gunnarr Gjúkason and Images of Snake-Pits. In W. Heizmann \& S. Oehrl (eds.). Bilddenkmäler zur germanischen Götter- und Heldensage. RGA-E, 9I. Berlin: Boston, $35 \mathrm{I}-373$.

Althaus, Sylvia. I993. Die gotländischen Bildsteine. Ein Programm. Göppinger Arbeiten zur Germanistik 588. Göppingen: Kümmerle.

Andersson, Aaron. 1968. L'art scandinave 2. La nuit des temps 29. Saint-Léger-Vauban: Zodiaque.

Andreeff, Alexander \& Potter, Rich. 20I4. Imaging Picture Stones. Comparative Studies of Rendering Techniques. In H. Alexandersson et al. (eds.). Med hjärta och hjärna. En vänbok till professor Elisabeth Arwill-Nordbladh. GOTARC Series A, Gothenburg Archaeological Studies, vol. 5. Göteborg: Göteborgs universitet, 669-689.

Andrén, Anders. 20I 2. From Sunset to Sunset. An Interpretation of the Early Gotlandic Picture Stones. In Gotländskt Arkiv 20I 2, 49-58.

Andrén, Anders. 20I4. Tracing Old Norse Cosmology. The World Tree, Middle Earth, and the Sun from Archaeological Perspectives. Vägar till Midgård I6. Lund: Nordic Academic Press.

Arne, Hjalmar \& Stolpe, Ture J. I9I2. Graffältet vid Vendel. Stockholm: Beckman.

Bailey, Richard. 1980. Viking Age Sculpture in Northern England. Collins Archaeology. London: Collins.

Bailey, Richard. 1996. England's Earliest Sculptors. Publications of the Dictionary of Old English, vol. 5. Toronto: Pontifical Inst. of Medieval Studies.

Bailey, Richard. 2003. Scandinavian Myth on Viking-period Stone Sculpture in England. In M. Clunies Ross (ed.), Old Norse Myths, Literature and Society. Proceedings of the I Ith International Saga Conference 2-7 July 2000. Odense: University of Sidney, I 5-23.

Bailey, Rosemary \& Bailey, Richard N. 1988. Corpus of Anglo-Saxon Stone Sculpture II: Cumberland, Westmorland and Lancashire North-of-the-Sands. Oxford: Oxford University Press. 
Bang, Anton Christian. I 879. Vøluspaa og de Sibyllinske Orakler. Christiania Videnskabsselskabs Forhandlinger I879, No. 9. Christiania: Dybwad.

Beck, Heinrich. I964. Einige vendelzeitliche Bilddenkmäler und die literarische Überlieferung. Bayerische Akademie der Wissenschaften. Philosophisch-Historische Klasse. Sitzungsberichte I964:6. München: Verlag der Bayerischen Akademie der Wissenschaften.

Blindheim, Martin. 1972-I973. Sigurds Saga i middelalderens billedkunst. Utstilling i Universitets Oldsaksamling I972-I973. Oslo: Universitet i Oslo.

Blindheim, Martin. I973. Fra hedensk figur til kristent forbilde. Sigurdsdiktningen i middelalderens billedkunst. In Iconografisk Post, vol. 1973:3, 3-28.

Bugge, Sophus. I88I-I889. Studier over de nordiske Gude- og Heltesagns Oprindelse. Christiania: Cammermeyer.

Bugge, Sophus. I 899. Nordiske Runeindskrifter og billeder paa Øen Man. In Aarbøger for Nordisk Oldkyndighed og Historie, vol. I4, 247-262.

Buisson, Ludwig. 1976. Der Bildstein Ardre VIII auf Gotland. Gottermythen, Heldensagen und Jenseitsglaube der Germanen im 8. Jahrhundert n. Chr. Abhandlungen der Akademie der Wissenschaften in Göttingen. Philologisch-Historische Klasse, Dritte Folge, Nr. I02. Göttingen: Vandenhoeck Ruprecht.

Böhner, Kurt. I982. Die Reliefplatten von Hornhausen. In Festschrift Hans-Jürgen Hundt zum 65. Geburtstag, Teil 3: Frühes Mittelalter. Jahrbuch des RGZM 23/24 (I976-1977). Mainz: RömischGermanischen Zentralmuseum Mainz, 89-I29.

Böttger-Niedenzu, Beata. I982. Darstellungen auf gotländischen Bildsteinen, vor allem des Typs $C$ und D, und die Frage ibres Zusammenhanges mit Stoffen der altnordischen Literatur. Hausarbeit zur Erlangung des Magister Grades an der LudwigMaximilians-Universität München. München: Universität München.

Calverley, William Slater. I883. The Sculptured Cross at Gosforth. In Transactions of the Cumberland and Westmorland Antiquarian and Archaeological Society I883, 373-404. 
De Vries, Jan. 1933. The Problem of Loki. FF Communications No. I Iо. Helsinki: Suomalainen Tiedeakatemia, Societas Scientiarum Fennica.

Cumont, Franz. 1942. Recherches sur le Symbolisme Funéraire des Romains. Paris: Geuthner.

Dronke, Ursula. I992. Vọluspá and Sibylline Traditions. In R. North $\&$ T. Hofstra (eds.). Latin Culture and Medieval Germanic Europe. Germania Latina I. Proceedings of the First Germania Latina Conference held at the University of Groningen, 26 May I989. Groningen: University of Groningen, 3-2I.

Dronke, Ursula. I997. The Poetic Edda, Volume II. Mythological Poems. Edited with Translation, Introduction and Commentary by Ursula Dronke. Oxford: Clarendon.

Egeler, Matthias. 2015. Avalon, $66^{\circ}$ Nord. Frühgeschichte und Rezeption eines Mythos. RGA-E 95. Berlin, Boston: de Gruyter.

Ellis Davidson, Hilda Roderick. I950. Gods and Heroes in Stone. In Sir C. Fox \& B. Dickins (eds.). The Early Cultures of NorthWest Europe. H. M. Chadwick Memorial Studies. Cambridge: Cambridge University Press, I23-I39.

Ellis Davidson, Hilda Roderick \& Gelling, Peter. I969. The Chariot of the Sun. And other Rites and Symbols of the Northern Bronze Age. New York: Praeger.

Ellis Davidson, Hilda Roderick. I988. Myths and Symbols in Pagan Europe. Early Scandinavian and Celtic Religions. Manchester: Manchester University Press.

Ellmers, Detlev. I970. Zur Ikonographie Nordischer Goldbrakteaten. In Jahrbuch des Römisch-Germanischen Zentralmuseums Mainz, vol. I7, 20I-284.

Ellmers, Detlev. 198I. Religiöse Vorstellungen der Germanen im Bildprogramm gotländischer Bildsteine und der Ostkrypta des Bremer Domes. In Jahrbuch der Wittheit zu Bremen, vol. XXV, $3 \mathrm{I}-54$.

Ellmers, Detlev. I986. Schiffsdarstellungen auf skandinavischen Grabsteinen. In H. Roth (ed.). Zum Problem der Deutung 
frühmittelalterlicher Bildinhalte. Akten des I. Internationalen Kolloquiums in Marburg a. d. Lahn, 15. bis I9. Februar I983. Veröffentlichungen des Vorgeschichtlichen Seminars der PhilippsUniversität Marburg a. d. Lahn, Sonderband 4. Sigmaringen: Philipps-Universität Marburg, 34 I-372.

Eshleman, Lori Elaine. 1983. The Monumental Stones of Gotland. A Study in Style and Motif. A Thesis submitted to the Faculty of the Graduate School of the University of Minnesota. Ann Arbor, Michigan: University Microfilms International.

Fingerlin, Gerhard. 20I0. Die ältesten christlichen Bilder der Alamannia. Zu Herkunft und Ikonographie der drei silbernen Phalerae aus dem Kammergrab von der „Gierhalde“ in Hüfingen, dem Hauptort der frühmittelalterlichen Baar. In V. Huth \& J. Regnath (eds.). Die Baar als Königslandschaft. Sigmaringen: Jan Thorbecke Verlag, 25-46.

Fuglesang, Signe Horn. 2004. Dekor, bilder og bygninger i kristningstiden. In J. V. Sigurðsson et al. (eds.). Religionsskiftet $i$ Norden. Brytinger mellom nordisk og europeisk kultur 800-I 200 e. Kr. Oslo: Senter for Studier i Vikingtid og Nordisk Middelalder, 197-294.

Graus, František. I977. Der Heilige als Schlachtenhelfer. Zur Nationalisierung einer Wundererzählung in der mittelalterlichen Chronistik. In K.-U. Jäschke \& R. Wenskus (eds.). Festschrift für Helmut Beumann zum 65. Geburtstag. Sigmaringen: Jan Thorbecke Verlag, 330-348.

Guber, Sonja. 20I I. Die Bildsteine Gotlands der Völkerwanderungsund Vendelzeit als Spiegel frühgeschichtlicher Lebenswelten. BAR International Series 2257. Oxford: Archaeopress.

Haavardsholm, Jørgen. I996. Gosforthkorset og dets kontekst. In M. Rindal (ed.). Studier $i$ kilder til vikingtid og nordisk middelalder. KULTs skriftserie 46. Oslo: Norges forskningsråd, I I7-I 46.

Hauck, Karl. I954: Herrschaftszeichen eines wodanistischen Königtums. In Jahrbuch für Fränkische Landesforschung, vol. I4, 9-66.

Hauck, Karl. 1957. Alemannische Denkmäler der vorchristlichen Adelskultur. In Zeitschrift für Württembergische Landesgeschichte, vol. I6:I, I-40. 
Hauck, Karl. I978. Bildforschung als historische Sachforschung. In K. Hauck \& H. Mordek (eds.). Geschichtsschreibung und geistiges Leben im Mittelalter. Köln, Wien: Böhlau, 27-70.

Hauck, Karl. I980. Die Veränderung der Missionsgeschichte durch die Entdeckung der Ikonologie der germanischen Bilddenkmäler, erhellt am Beispiel der Propagierung der Kampfhilfen des MarsWodan in Altuppsala im 7. Jahrhundert. Zur Ikonologie der Goldbrakteaten XX. In Westfalen. Hefte für Geschichte, Kunst und Volkskunde, vol. 57, 227-307.

Hauck, Karl. I98I. Die bildliche Wiedergabe von Götter- und Heldenwaffen im Norden seit der Völkerwanderungszeit. Zur Ikonologie der Goldbrakteaten XVIII. In R. Schmidt-Wiegand (ed.). Wörter und Sachen im Lichte der Bezeichnungsforschung. Arbeiten zur Frühmittelalterforschung I. Berlin, New York: de Gruyter, I68-269.

Hauck, Karl. I982. Zum zweiten Band der Sutton Hoo-Edition. In Frühmittelalterliche Studien, vol. 16, 319-362.

Hauck, Karl. I983a. Text und Bild in einer oralen Kultur. Antworten auf die zeugniskritische Frage nach der Erreichbarkeit mündlicher Überlieferung im frühen Mittelalter. Zur Ikonologie der Goldbrakteaten XXV. In Frühmittelalterliche Studien, vol. I7, 5 I0-599.

Hauck, Karl. I983b. Dioskuren in Bildzeugnissen des Nordens vom 5. bis zum 7. Jahrhundert. Zur Ikonographie der Goldbrakteaten XXVIII. In Jahrbuch des RGZM, vol. 30, 435-464.

Hauck, Karl. I984. Dioskuren, \$4-6. In RGA 5, 484-494.

Hauck, Karl. 1994. Altuppsalas Polytheismus exemplarisch erhellt mit Bildzeugnissen des 5. - 7. Jahrhunderts. Zur Ikonologie der Goldbrakteaten LIII.In H.Uecker (ed.). Studien zum Altgermanischen. Festschrift für Heinrich Beck. RGA-E II. Berlin, New York: de Gruyter, 197-302.

Hauck, Karl et al. 1985-1989. Die Goldbrakteaten der Völkerwanderungszeit. Ikonographischer Katalog I-3. Münstersche Mittelalter-Schriften 24, I, I-3, 2. München: Fink. 
Heinzle, Joachim. 20Iо. Die Nibelungen. 2nd Edition. Darmstadt: Primus.

Helmbrecht, Michaela. 20I I. Wirkungsmächtige Kommunikationsmedien. Menschenbilder der Vendel-und Wikingerzeit und ibre Kontexte. Acta Archaeologica Lundensia, Series Prima in $4^{\circ} 30$. Lund: Lunds Universitet.

Herlin Karnell, Maria et al. (ed.). 20I2. Gotland's Picture Stones. Bearers of an Enigmatic Legacy. Gotländskt Arkiv 84. Visby: Fornsalen Publishing.

Heusler, Andreas. I94I. Die altgermanische Dichtung. 2nd Edition. Potsdam: Athenaion.

Holmqvist, Wilhelm. I939. Kunstprobleme der Merowingerzeit. Stockholm: Wahlström \& Widstrand.

Holmqvist Wilhelm. I952. De äldsta gotländska bildstenarna och deras motivkrets. In Fornvännen, vol. 47, I-20.

van der Horst, Koert et al. I982-I984. Utrecht-Psalter. Im Originalformat der Handschrift 32 aus dem Besitz der Bibliotheek der Rijksuniversiteit te Utrecht. Codices selecti phototypice impressi 75-76. Bd. I: Vollständige Faksimile-Ausgabe, Bd. 2: Kommentar von Koert van der Horst, übersetzt aus dem Holländischen von Johannes Rathofer. Graz: Akademische Druck- und Verlagsanstalt.

Horst, Simone. 20ıо. Merlin und die Völva. Weissagungen im Altnordischen. Münchner Nordistische Studien 5. München: Herbert Utz.

Hultgård, Anders. I990. Old Scandinavian and Christian Eschatology. In T. Ahlbäck (ed.). Old Norse and Finnish Religions and Cultic Place-Names. Based on Papers Read at the Symposium on Encounters Between Religions in Old Nordic Times and on Cultic Place-Names Held at Ábo, Finland, on the I gth-2 Ist of August 1987. Scripta Instituti Donneriani Aboensis XIII. Åbo: Donner Institute, 344-357.

Hyenstrand, Åke. 1989. Socknar och stenstugor. Om det tidiga Gotland. SAR, Nr. 22. Stockholm: Stockholm University. 
Imer, Lisbeth. 200I. Gotlandske billedsten. Datering af Lindqvists gruppe C og D. In Aarbøger for nordisk oldkyndighed og historie 200I (erschienen 2004), 47-III.

Imer, Lisbeth. 20I2. The Viking Period Gotlandic Picture Stones. A Chronological Revision. In Gotländskt Arkiv, vol. 84, I I 5-I I 8.

Johansson, Karl G. 20I3. Voluspá, The Tiburtine Sibyl, and the Apocalypse in the North. In T. Gunnell \& A. Lassen (eds.). The Nordic Apocalypse. Approaches to Voluspá and Nordic Days of Judgement. Acta Scandinavica. Aberdeen Studies in the Scandinavian World, vol. 2. Turnhout: Brepols, I6I-I84.

Kitzler Åhfeld, Laila. 2009. Keltiskt eller kontinentalt? Om mallanvändning på Gotlands bildstenar. In C. Hedenstierna-Jonson et al. (eds.). Spaden och pennan. Minnesbok tillägnad Erik B. Lundberg och Bengt G. Söderberg. Stockholm: Oeisspesis, I 3 I-I 54 .

Kitzler Åhfeld, Laila. 20I 2. Picture Stone Workshops and Handicraft Traditions. In Gotländskt Arkiv 84, I83-194.

Kitzler Åhfeld, Laila. 2013. 3D-scanning of Gotland Picture Stones. With Supplementary Material: Digital catalogue of ${ }_{3} \mathrm{D}$ data. In Journal of Nordic Archaeological Science, JONAS, vol. I 8 (2013), $55-65$.

Kitzler Åhfeld, Laila. 20I5. Picture-Stone Workshops on Viking Age Gotland. A Study of Craftworkers' Traces. In W. Heizmann \& S. Oehrl (eds.). Bilddenkmäler zur germanischen Götter- und Heldensage. RGA-E 9I. Berlin, Boston: de Gruyter, 397-43I.

Kopár, Lilla. 20I2. Gods and Settlers. The Iconography of Norse Mythology in Anglo-Scandinavian Sculpture. Studies in the Early Middle Ages, vol. 25. Turnhout: Brepols.

Krappe, Alexander H. I940-I94 I. The Snake Tower. In Scandinavian Studies, vol. I6, 22-33.

Kure, Henning. 2013. Wading Heavy Currents. Snorri's use of Vọluspá 39. In T. Gunnell \& A. Lassen (eds.). The Nordic Apocalypse. Approaches to Voluspá and Nordic Days of Judgement. Acta Scandinavica. Aberdeen Studies in the Scandinavian World, vol. 2. Turnhout: Brepols, 79-9I. 
Lamm, Jan Peder \& Nylén, Erik. 2003. Bildstenar. 3rd edition. Värnamo: Fälth \& Hässler.

Lang, James. I989. Pre-Conquest Sculpture in Eastern Yorkshire. In C. Wilson (ed.). Medieval Art and Architecture in the East Riding of Yorkshire. Conference Transactions for the year I983. London: The British Archaeological Association, I-8.

Lindqvist, Sune. I94I-I942. Gotlands Bildsteine I-II. Stockholm: Wahlström \& Widstrand.

Lindqvist, Sune. I962. Jättestenen från Sanda och andra nyfunna bildstenar. In Gotländskt Arkiv, vol. 34, 7-22.

Margeson, Sue. I980. The Volsung Legend in Medieval Art. In F. G. Andersen et al. (eds.). Medieval Iconography and Narrative. A Symposium. Odense: Odense University Press, I 83-2 I I.

McKinnell, John. 1994. Both One and Many. Essays on Change and Variety in Late Norse Heathenism. Philologia I. Rome: Il Calamo.

McKinnell, John. 2008. Voluspá and the Feast of Easter. In Alvísmál, vol. I 2, 3-28.

Meyer, Elard Hugo. I889. Völuspa. Eine Untersuchung. Berlin: Mayer \& Müller.

Mundal, Else. I998-2000. Androgyny as an Image of Chaos in Old Norse Mythology. In Maal och Minne I998-2000, I-9.

Nedoma, Robert. 1988. Die bildlichen und schriftlichen Denkmäler der Wielandsage. Göppinger Arbeiten zur Germanistik Nr. 490. Göppingen: Kümmerle.

Nordland, Odd. I949. Ormegarden. In Viking. Tidskrift for norrøn arkeologi, vol. I3, 77-I 26.

North, Richard. 200I. Loki's Gender. Or why Skaði Laughed. In K. E. Olsen \& L. A. J. R. Houwen (eds.). Monsters and the Monstrous in Medieval Northwest Europe. Mediaevalia Groningana, New Series, Volume III. Leuven: Peeters, I 4 I-I 5 I.

North, Richard. 2003. Voluspá and the Book of Revelation. In R. Simek \& J. Meurer (eds.). Scandinavia and Christian Europe in the Middle Ages. Papers of the I $2^{\text {th }}$ International Saga Conference, 
Bonn/Germany, $28^{\text {th }}$ July $-2^{\text {nd }}$ August 2003. Bonn: Universität Bonn, 403-4I 2.

Oehrl, Sigmund. 2006. Zur Deutung anthropomorpher und theriomorpher Bilddarstellungen auf den spätwikingerzeitlichen Runensteinen Schwedens. Wiener Studien zur Skandinavistik I6. Wien: Praesens.

Oehrl, Sigmund. 2009. Wieland der Schmied auf dem Kistenstein von Alskog kyrka und dem Runenstein Ardre kyrka III. Zur partiellen Neulesung und Interpretation zweier gotländischer Bildsteine. In H. Beck et al. (eds.). Analecta Septentrionalia. Beiträge zur nordgermanischen Kultur- und Literaturgeschichte. RGA-E 65. Berlin, New York: de Gruyter, 540-566.

Oehrl, Sigmund. 20I2a. New Iconographic Interpretations of Gotlandic Picture Stones Based on Surface Re-Analysis. In Gotländskt Arkiv 2OI 2, 9I-IO4.

Oehrl, Sigmund. 20 I 2b. Bildliche Darstellungen vom Schmied Wieland und ein unerwarteter Auftritt in Walhall. In A. Pesch \& R. Blankenfeldt (eds.). Goldsmith Mysteries. The Elusive Gold Smithies of the North. Papers Presented at the Workshop Organized by the Centre for Baltic and Scandinavian Archaeology (ZBSA), Schleswig, June $20^{\text {th }}$ and $2 I^{\text {th }}$, $20 I I$. Schriften des Archäologischen Landesmuseums. Ergänzungsreihe 8. Neumünster: ZBSA, 279-335.

Oehrl, Sigmund. 20I3a. Review About Guber 20I I. In Zeitschrift für deutsches Altertum und deutsche Literatur, vol. I42:2, 250-260.

Oehrl, Sigmund. 2013 b. Das Uroboros-Motiv im germanischen Altertum und seine Kontexte. Eine Übersicht. In I. Heske et al. (eds.). Landschaft, Besiedlung und Siedlung. Archäologische Studien im nordeuropäischen Kontext. Festschrift für Karl-Heinz Willroth zu seinem 65. Geburtstag. Göttinger Schriften zur Vor- und Frühgeschichte 33. Neumünster, Hamburg: Wacholtz/Murmann, 45 5-468.

Oehrl, Sigmund. 20I4. Uroboros. In Germanische Altertumskunde Online (GAO), Update 2/20I4.

Oehrl, Sigmund. 2015. Möglichkeiten der Neulesung gotländischer Bildsteine und ihre ikonographische Auswertung. Ausgewählte 
Beispiele und Perspektiven. In W. Heizmann \& S. Oehrl (eds.). Bilddenkmäler zur germanischen Götter- und Heldensage. RGA-E 9I. Berlin, Boston: de Gruyter, 219-259.

Oehrl, Sigmund. 20 16. Horned Ship-Guide. An Unnoticed Picture Stone Fragment from Stora Valle, Gotland. In Fornvännen, vol. I I I, 53-55.

Oehrl, Sigmund. 20I7a. Der göttliche Schiffsbegleiter mit dem 'Hörnerhelm'. Ein bislang unbekanntes wikingerzeitliches Bildsteinfragment aus St. Valle im Kirchspiel Rute auf Gotland. In Zeitschrift für deutsches Altertum und deutsche Literatur, vol. I 46:I, I-40.

Oehrl, Sigmund. 20I7b. Documenting and interpreting the picture stones of Gotland. Old problems and new approaches. In Current Swedish Archaeology, vol. 25, 87-I 22.

Olrik, Axel. 1922. Ragnarök. Die Sagen vom Weltuntergang. Übertragen von Wilhelm Ranisch. Berlin, Leipzig: de Gruyter.

Pétur Pétursson. 2013. Manifest and Latent Biblical Themes in Voluspá. In T. Gunnell \& A. Lassen (eds.). The Nordic Apocalypse. Approaches to Voluspá and Nordic Days of Judgement. Acta Scandinavica. Aberdeen Studies in the Scandinavian World, vol. 2. Turnhout: Brepols, I 85-202.

Quast, Dieter. 2002. Kriegerdarstellungen der Merowingerzeit aus der Alamannia. In Archäologisches Korrespondenzblatt, vol. 32, 267-280.

Quast, Dieter. 2009. Merovingian Period Equestrians in Figural Art. In A. Bliujiene (ed.). The Horse and Man in European Antiquity. Worldview, Burial Rites, and Military and Everyday Life. Archaeologia Baltica, vol. I I. Klaipeda: Klaipeda University, 330-342.

Reichert, Hermann. 2003. Die Nibelungensage im mittelalterlichen Skandinavien. In J. Heinzle et al. (eds.). Die Nibelungen. Sage Epos - Mythos. Wien: Reichert, 29-88.

Reitzenstein, Richard. 1924. Weltuntergangsvorstellungen. Eine Studie zur vergleichenden Religionsgeschichte. Sonderabdruck aus Kyrkohistorisk Årsskrift I 924. Uppsala: Lundquistska Bokhandelen. 
Samplonius, Kees. 20I3. The Background and Scope of Voluspá. In T. Gunnell \& A. Lassen (eds.). The Nordic Apocalypse. Approaches to Voluspá and Nordic Days of Judgement. Acta Scandinavica. Aberdeen Studies in the Scandinavian World, vol. 2. Turnhout: Brepols, II3-I45.

Schreiner, Klaus. 2000. Märtyrer, Schlachtenhelfer, Friedensstifter. Krieg und Frieden im Spiegel mittelalterlicher und frühneuzeitlicher Heiligenverehrung. Otto-von-Freising-Vorlesungen der Katholischen Universität Eichstätt. Wiesbaden: Leske \& Budrich.

Schreiner, Klaus. 2004. SIGNA VICTRICIA. Heilige Zeichen in kriegerischen Konflikten des Mittelalters. In G. Althoff (ed.). Zeichen - Rituale - Werte. Internationales Kolloquium des Sonderforschungsbereichs 496 an der Westfälischen Wilhelms-Universität Münster. Münster: Rhema, 259-300.

von See, Klaus. I98I. Germanische Heldensage. Stoffe, Probleme, Methoden. 2nd Edition. Frankfurt am Main: Athenaion.

von See, Klaus et al. 2009. Kommentar zu den Liedern der Edda 6: Heldenlieder. Brot af Sigurðarkviðo, Guðrúnarkviða I, Sigurðarkviða in skamma, Helreið Brynhildar, Dráp Niflunga, Guðrúnarkviða II, Guðrúnarkviða III, Oddrúnargrátr, Strophenbruchstücke aus der Volsunga saga. Heidelberg: Winter.

Shetelig, Haakon. I933. Vikingeminner $i$ Vest-Europa. Instituttet for Sammenlignende Kulturforskning, Serie A: Forelesninger I6. Oslo, Leipzig: Aschenhoug, Harrassowitz.

Sigurður Nordal. I980. Völuspá. Herausgegeben und kommentiert von Sigurður Nordal. Aus dem Isländischen übersetzt und mit einem Vorwort zur deutschen Ausgabe von Ommo Wilts. Texte zur Forschung 33. Darmstadt: Wissenschaftliche Buchgesellschaft.

Staecker, Jörn. 2006. Heroes, Kings and Gods. Discovering Sagas on Gotlandic Picture-Stones. In A.Andrén et al. (eds.). Old Norse Religion in Long-Term Perspectives. Origins, Changes, and Interactions. An international Conference in Lund, Sweden, June 3-7, 2004. Vägar till Midgård 8. Lund: Nordic Academic Press, 363-368.

Stephens, George. I884. Prof. S. Bugge's Studier over nordisk mythologi. Supplement. In Aarbøger for Nordisk Oldkyndighed og Historie I $884, \mathrm{I}-47$. 
Steinsland, Gro. 20I3. Voluspá and the Sibylline Oracles with a Focus on the Myth of the Future. In T. Gunnell \& A. Lassen (eds.). The Nordic Apocalypse. Approaches to Voluspá and Nordic Days of Judgement. Acta Scandinavica. Aberdeen Studies in the Scandinavian World, vol. 2. Turnhout: Brepols, I47-I60.

Ström, Folke. 1956. Loki. Ein mythologisches Problem. Acta Universitatis Gothoburgensis. Göteborgs Universitets Årsskrift Vol. LXII, I95 6:8. Göteborg: Elander.

Varenius, Björn. I992. Det Nordiska Skeppet. Teknologi och samhällsstrategi $i$ vikingatid och medeltid. Stockholm Studies in Archaeology ıo. Stockholm: Stockholms Universitet.

Vierck, Hayo. I98 I. Imitatio imperii und interpretatio Germanica vor der Wikingerzeit. In R. Zeitler (ed.). Les Pays du Nord et Byzance (Scandinavie et Byzance). Actes du colloque nordique et international de byzantinologie, tenu à Upsal 20-22 avril 1979. Acta Universitatis Upsaliensis Figura, N. S. I9. Uppsala: Almqvist \& Wiksell, 64-I I3.

Westphal, Florian. 2004. Untersuchungen zur späten Bildsteingruppe Gotlands. In M. Müller-Wille (ed.). Zwischen Tier und Kreuz. Untersuchungen zur wikingerzeitlichen Ornamentik im Ostseeraum. Studien zur Siedlungsgeschichte und Archäologie der Ostseegebiete, Bd. 4. Neumünster: Wachholtz, 377-454.

Williams, John. 1994-2003. The Illustrated Beatus. A Corpus of Illustrations of the Commentary on the Apocalypse, Vol. I-5. London: Miller.

Wilson, David M. I995. Vikingatidens Konst. Signums svenska konsthistoria 2. Lund: Bokförlag Signum.

Wilson, David. I998. The Gotland Picture-Stones. A Chronological Re-Assessment. In A. Wesse (ed.). Studien zur Archäologie des Ostseeraumes. Von der Eisenzeit zum Mittelalter. Festschrift für Michael Müller-Wille. Neumünster: Wachholtz, 49-52. 


\title{
Response
}

\author{
Anne-Sofie Gräslund \\ University of Uppsala
}

The RTI-method itself, together with some good examples of its benefits, was published by Oehrl after The Picture Stone Symposium in Visby 20II. ${ }^{\mathrm{I}}$ It seems to be a very useful tool for scholars to be able to see more details of the original carvings than you can with the naked eye. At the Mythology Conference in Stockholm 20I 5 Oehrl answered in the negative my question of whether the method is technically very difficult or expensive; that means that we probably can expect many more exciting results in the future. However, it is worth mentioning that, basically, Sune Lindqvist used the same technique with oblique light from different angles, ${ }^{2}$ but of course, today's RTI-technique is much more elaborated, developed and powerful.

Sigmund Oehrl starts by showing that the iconography of the Gotlandic picture stones may provide new insights into ancient Germanic and Viking mythology, both regarding motifs that are totally unknown from literary tradition, such as the horned shipguide on the stone from Stora Valle in Rute Parish recently published by him, ${ }^{3}$ and motifs known from literature written down centuries later than the images in question.

The first example taken up in his current paper, the motif traditionally called Gunnarr in the snake pit is represented on the stone from Hunninge in Klinte parish. The RTI-picture shows that the person in the snake pit is not a man but a woman, having long hair, set up in a pigtail, and a long dress, both female characteristics. Oehrl's idea is either that there could be an influence from the Christian eschatology taken over into Old Norse mythology, expressed in Voluspá, stanzas 38-39 where the hall of the Sindre dynasty formed by snakes is described, or perhaps more likely, compared to the scene of the same motif on the picture stone Ardre VIII, the figure in the snake-filled enclosure may instead be interpreted as Loki, who is known for some bisexual characteristics. There Loki is depicted with a braid, the same hairstyle as his wife 
Sigyn. The two women outside the enclosure may be interpreted as Sigyn with the bowl to collect the poison from the snake and Skaði holding a snake. However, it could be mentioned that the story about Sigurðr Fáfnisbani including that of Gunnarr in the snake pit were known in Scandinavia as seen from images on Late Viking Age rune stones. A good example of an image of Gunnarr comes from the Västerljung Stone (Sö 40) where Gunnarr plays the harp with his feet.

The second monument discussed by Oehrl is the large Migration Period stone IV from Sanda Church, dated to probably the $6^{\text {th }}$ century. The upper part was found at the beginning of the $20^{\text {th }}$ century. On the lower part, not discovered until 1956 , the RTI-picture showed a rider with a spear in his hand, earlier totally unknown. A horizontal line carved over the stone surface is regarded as the border between the upper world and the underworld. Anders Andrén has connected the iconography of the Sanda Stone with a Bronze Age sun cult and the journey of the sun through the day and night. ${ }^{4}$

Regarding the rider, Oehrl mentions several parallels, mainly from the Merovingian Period, to this motif, from picture stones, gold bracteates and sheet foils from helmets, and he concludes with references to Wilhelm Holmqvist that its origin probably came from early Christian art on the continent and was re-interpreted against the background of indigenous tradition. This is a statement that I entirely agree with - so much of the Scandinavian iconography of the second half of the first millennium can be traced back to the early Christian art on the continent and then in its turn back to pre-Christian art in the Near East. ${ }^{5}$

Also, in this case there is interesting comparative material in the iconography of Late Viking Age rune stones. Images of riders occur on a number of Uppland rune stones and in my view several of them can be interpreted as holy riders, especially the one on stone U 69I from Söderby in Arnö Parish, where the centrally placed rider has a raised sword in one hand and a processional cross in the other. In Christian iconography riders, often armed, occur, generally interpreted as Militia Christi, representing the army of Christ.

However, for the rune stones in question I find another hypothesis more attractive, put forward by the Scottish archaeologist 
Martin Goldberg in his work on the Pictish symbol stones. From the $8^{\text {th }}$ century onwards, the Pictish symbol stones seem to have a mixture of pagan and Christian motifs, in the same way as pre-Christian and Christian representations are mixed on our picture stones and rune stones. It is easy to believe that, in a transition phase, motifs with a pagan as well as a Christian meaning were popular. There are many examples from various times and areas that, during conversion, customs from the old religion were accepted or tolerated, only given a new interpretation that fitted in with the new religion, the so-called Interpretatio (for example) Scandinavica. On some Pictish stones there are riders, and these are traditionally interpreted as hunting scenes. Goldberg's idea is that in this apparent motif there might be a hidden meaning that the picture is an allusion of the so-called Adventus motif, the entry of Christ to Jerusalem on Palm Sunday, when he is welcomed as Messiah. ${ }^{6}$ In my view this is supported by Maria Elena Ruggerini, who, in an article on the Anglo-Saxon liturgy of Easter including Palm Sunday, makes a comprehensive investigation of sources. She points out that the ninth-century hymn Gloria laus et honor, praising Christ as the pious and righteous king, redeemer of humankind, composed by Theodulph, Bishop of Orléans and based on Psalm 24 exists in a version Canterbury Benedictional with added verses. One of them asks: Quis rex hic equitat, cui Gloria redditur ista? (Who is this king who comes riding here, to whom glory is due?). ${ }^{7}$ Obviously, the Sanda Stone is much earlier, probably from the $6^{\text {th }}$ century, but as Oehrl argues in his article, it is more likely that the Gotlandic stone carver did not intend to depict a Christian saint or the Roman emperor - on the contrary, he borrowed the motif from continental or Mediterranean art and, as it was laden with symbolism in the Old Norse mythology, he re-interpreted it against the background of domestic tradition.

\section{Notes}

I. Oehrl 20I2:9Iff.

2. Nylén \& Lamm 2003:3.

3. Oehrl 20I6:55ff. 
4. Andrén 20I 2:55ff.

5. Gräslund 20I4:24ff.

6. Goldberg 20I 2:I6off.

7. Ruggerini 20II:2I3ff.

\section{References}

Andrén, Anders. 20I2. From Sunset to Sunset. An Interpretation of the Early Gotlandic Picture Stones. In Gotländskt Arkiv 2012, $49-58$.

Goldberg, Martin. 20 I2. Ideas and Ideologies. In D. Clarke et al. (eds.). Early Medieval Scotland. Individuals, Communities and Ideas. Edinburgh: National Museums Scotland Enterprises, I4 I-203.

Gräslund, Anne-Sofie. 20I4. En påfågel i Odensala? Några reflexioner om ikonografin på runstenarna vid Harg. In Situne Dei 2OI $4,22-3$ I.

Nylén, Erik \& Lamm, Jan Peder. 2003. Bildstenar. 3:e upplagan. Stockholm: Gidlunds Förlag.

Oehrl, Sigmund. 20 I 2. New Iconographic Interpretations of Gotlandic Picture Stones Based on Surface Re-analysis. In Gotländskt Arkiv 2OI 2, 9I-IO4.

Oehrl, Sigmund. 2016. Horned Ship-guide. An Unnoticed Picture Stone Fragment from Stora Valle in Rute, Gotland. In Fornvännen I I I/2OI $6,53-55$.

Ruggerini, Maria Elena. 20 I I. A Just and Riding God. Christ's Movement in the Descent into Hell. In D. Anlezark (ed.). Myths, Legends, and Heroes. Essays on Old Norse and Old English Literature in Honour of John McKinnel. Toronto, Buffalo, London: University of Toronto Press, 207-267. 
